\title{
5. Shifting Positions of the Sexual Self
}

This chapter examines how queer migrant women perceive their sexuality to have changed through migration. In order to make sense of the development of their sexual Self, in their narratives, interviewees revisit the places they have inhabited in the past, renegotiating what they perceive to have been prevailing ideas about sexuality in these places, and their own position in relation to these norms both before and after migration. These revisitations are mutually constitutive with interviewees' shifting positionalities vis-à-vis the figure of the lesbian. From the narratives of queer migrant women, the lesbian appears as a central figure in dominant discourses around female same-sex sexuality in Switzerland, which forces them to position themselves in relation to it. This chapter focuses on these fractured processes of disidentification, also examining the ways in which these negotiations in themselves reproduce and subvert the figure of the lesbian.

The following discussion centers on what I call different 'biographical trajectories' that I have derived from the generated data. These trajectories represent polythetic or 'natural' types of certain aspects of participants' biographies, so called because they are based on empirical data rather than for instance theoretical reflection only. The aim of generating types is to reduce the complexity of real life by ordering the data in a specific way. Individual cases, or in this case, stories, are grouped together in such a way that within a group or 'type' these stories are as homogenous as possible with respect to one or several given aspects. At the same time, types should differ among each other as much as possible with respect to these same aspects. Polythetic types are never clear-cut in the sense that individuals or individual stories assigned to a type do not exhibit the exact same characteristics. Some stories fit more, some less into the defined type pattern (Kukartz 2006:4052-4023). In this chapter, the aspect ordering the data into types was the way in which interviewees' perception of their sexual Selves shifted through migration, as well as the conditions and effects of these shifts. Since they are about a dynamic rather than a fixed characteristic, I name these types 'biographical trajectories.'

Three such biographical trajectories were derived from the interviews. The first trajectory, "Now I can say: I'm a lesbian," represents narratives of participants who have come to identify as lesbians while living in Switzerland. This includes participants who did 
not engage in same-sex relationships before emigrating as well as participants who entertained same-sex relationships but were not embedded in a sexual minority subculture. The central focus is on the story of Teresa Ruiz, who never felt attracted to women before emigrating from Cuba, but who has since developed a lesbian identity in Switzerland. The second trajectory, "I was totally shocked," engages with Siti Mohd Amin's narrative. Siti Mohd Amin had been a member of a Malaysian sexual minority community before leaving for Switzerland. While she has maintained connections to women-loving Malaysian women via transnational technologies after migration, in Switzerland she finds herself unable to create a place for herself in the local lesbian community. The third trajectory, "It's like a stamp," discusses Efra Mahmoud's account. Efra Mahmoud felt attracted to women before emigrating from Egypt but had never acted on those feelings. Now she lives in a same-sex partnership in Switzerland, but she does not identify as a lesbian. Each of these sub-chapters draws on material from other biographies to complement the analysis of the themes around the shifting sexual positionalities that dominate these three 'lead' biographies.

It has to be noted that the boundary between those who did and did not engage in same-sex relationships before migration needs to be framed in terms of a continuum rather than a clear-cut line. Some had not been attracted to other women at all before migrating; others did not entertain same-sex relationships but retrospectively diagnose that they felt 'different' or like they 'did not fit in' all along; some did engage in intimacies with women but did not think of these acts and relationships as a valid alternative to the heteronormative biographies earmarked for them; and some identified as lesbian or another same-sex identity before migration and had circulated in these subcultures. Moreover, these trajectories are to be understood as ongoing developments rather than completed tales. A participant who did not identify as a lesbian at the time of the interview may have done so three years later.

\section{1 "Now I can say I'm a lesbian": Becoming a Lesbian in Switzerland}

Many participants in this study had not thought of themselves in terms of same-sex desire or had not engaged in same-sex relationships before emigrating but came to identify as lesbians after migrating to Europe. This sub-chapter is concerned with this biographical trajectory. Working outwards from the story of Teresa Ruiz, the analysis extends to a broader examination of narratives about the assumption of a lesbian identity in Switzerland. This notably also includes a discussion of the accounts of interviewees who had already entertained same-sex relationships before emigration but were not embedded in a sexual minority subculture and understood their sexuality in terms of a practice rather than a social identity. This examination exposes the process of becoming a lesbian in Switzerland as one of personal development, learning and 'integration' on the one hand; and as a disciplinary process on the other. 


\subsubsection{Deskilling and Social Isolation: Arriving in Switzerland}

Teresa Ruiz, aged thirty-four, lives in a small, rented house with a garden in a quiet neighborhood in Basel. She rents the house with her much younger partner Angela Hieber, a Swiss citizen. The women plan to have children together; Teresa Ruiz is already working on insemination with a gay donor couple. Once the child is born, the couple plan for Teresa Ruiz to take on the role of breadwinner while her partner looks after the child.

Teresa Ruiz came to Switzerland eleven years prior to the interviews. Her friends, she says, are Swiss - "all of them" as she emphasizes - but she identifies as "95 Prozent Kubanerin und fünf Prozent Baslerin" - "95 percent Cuban and five percent Basler." She says she has come to a point where she not only misses Cuba when she is in Switzerland but also misses Switzerland when she is in Cuba, where she visits her family twice a year. Still, she feels at home in both places - she has "found the middle."

Teresa Ruiz was the fourth of her siblings to migrate from Cuba to Switzerland. It had not been her intention to stay in Switzerland permanently; she had merely wanted to come and help her sister with her newborn child for a few weeks. However, while planning her trip to Switzerland, the Cuban government announced a travel ban for Cuban citizens with an academic education. Even before leaving for Switzerland, Teresa Ruiz therefore had a premonition that her life was about to change radically. Indeed, once in Switzerland she had three months to decide whether she wanted to stay permanently or to return to Cuba and not be able to leave her country anymore.

Und ja, dann habe ich mich müssen entscheiden, mir ist wirklich schwer gefallen weil ich eigentlich so eine sagen wir mal Vorzugsbehandlung bekommen habe von meiner Mutter und dort hatte ich alles eigentlich meine Freundinnen- alles also, ich hatte wirklich nicht vor da zu bleiben, es ist fast ein Druck gewesen weil, eben mir ist, ja, wichtiger gewesen damals meine Freiheit und deshalb-. Aber das war wirklich für mich ein Dilemma weil ich, eben, es ist das erste Mal, das ich von meiner Mutter getrennt gewesen bin und [ich] hätte nie gedacht, dass ich das eigentlich überhaupt kann so ohne meine Mutter zu leben [...]. Und als ich dann die Entscheidung getroffen habe [...] da habe ich einfach drei Monate lang nur brüelt und brüelt.

And yes, then I had to decide, it was really difficult for me because I had, let's say, a preferential treatment by my mother and I had everything there really, my friends - everything, I really had not intended to stay, it was almost a kind of pressure because, well, my freedom was more important to me at the time, and that's why-. That really was a dilemma for me because, well, it was the first time I was separated from my mother and [I] would never have thought that I would be able at all to live like that, without my mother [...]. And when I had taken the decision [...] for three months I just cried and cried.

-Teresa Ruiz

While the prospect of being able to help her mother financially also played a crucial role in her decision to stay, "freedom" is the keyword by which Teresa Ruiz judges her life in Switzerland throughout the interview; at first the freedom to move about as she likes, and later, when she came to identify as a lesbian, her sexual freedom. 
So, Teresa Ruiz applied for, and obtained, asylum in Switzerland. After months of grief, she resolved to "just look forward" and "integrate" - a path that was riddled with obstacles. As her professional qualifications from Cuba were only partially recognized in Switzerland, at the age of twenty-four she had to relaunch her professional career "von Null" - "from scratch." She describes the initial months at her new workplace that followed as "hell." She felt lost culturally and struggled with the loathsome German language. But she steadily worked her way up. Eleven years later, at the time of the interviews, she is the proud and highly appreciated leader of two teams in a health institution in Basel.

Teresa Ruiz' lengthy professional catch-up was accompanied by a private life marked by homesickness, a far-reaching social isolation and a series of unsatisfying relationships with men. Not yet knowing German, she sought friendship and intimacy among the Spanish and Italian communities in Basel. Since she did not want to be a permanent burden to her sister, she soon moved to a one-room apartment, but being used to living in a big family house, she detested living alone and ended up spending most of her time in her Spanish friend María García’s home; as Teresa Ruiz says, María García's family virtually "adopted" her during this period.

I have introduced Teresa Ruiz' work biography here for reasons beyond a mere contextualization of the case. On the one hand, Teresa Ruiz' story underscores the critique by Swiss feminist migration scholars who have analyzed the impact deskilling has on immigrant women's self-esteem and integration into the Swiss labor market (Baghdadi 2011, Riaño and Baghdadi 2007, Riaño et al. 2006). The bias of the sample analyzed in this study towards highly skilled women suggests that for many women interviewed here, this critique is particularly relevant and applicable. On the other hand, as will be shown in the following, the effects of discrimination against skilled migrant women in the labor market converges with issues the women face due to their sexual dissidence. This subjects them to a disproportionate risk of personal crises, especially in the first years after immigration.

\subsection{2 "Now I can say: I'm a lesbian": Coming Home to the Lesbian Identity}

Upon arrival in Switzerland, Teresa Ruiz' ideas about her future were still firmly anchored in the heteronormative ideal:

Das Bild wo ich gehabt habe [in Kuba] ich täte meinen Ex-Freund heiraten, Kinder haben, wie meine Mutter einfach- leben [...] also so viele Vorstellungen hat man in Kuba nicht, einfach schaffen [=arbeiten] und, eben, Familie gründen, mehr gibt es wirklich nicht viel eben weil reisen kannst du ja nicht oder nur halt in Kuba und aber eben damals war ich mehr karriereorientiert, oder? Da wollte ich halt noch mehr mit den Karriere machen in Kuba. [Aber] das ist klargewesen, Familie, Kinder, heiraten, ja das ist klar gewesen. Absolut.

The image I had [in Cuba] was that I would marry my ex-boyfriend, have children, like my mother- just live [...] well you don't have many ideas in Cuba, just work and, well, build a family, there's not much more than that because you can't travel or only within Cuba but at the time I was more career oriented, you know? I wanted to make more of 
my career in Cuba. [But] that was clear, family, children, marrying, yes, that was clear. Absolutely.

-Teresa Ruiz

The possibility of marriage and children, two of the three central pillars in Teresa Ruiz' imagined future (the third being her career), became more and more remote as Teresa Ruiz went through a series of short and unhappy relationships with men in Switzerland. In a Spanish center in Basel, Teresa Ruiz eventually met a man with whom she started a relationship, but she told him from the start that he would have to accept the fact that her friend - "my María" - and her family come first. Although her relationship to María García was not sexual, Teresa Ruiz thus thought of this relationship in terms of a direct competition to her relationship with her male partner. However, at the time, she did not question her sexual preferences. When María García and her family returned to Spain, in her devastation, Teresa Ruiz made the rash decision to marry her boyfriend:

Und dann später habe ich den Exmann kennen gelernt, und dann [...] sind wir zwei] ]ahre zusammen gewesen. [...] Und in diesen zwei] ]ahren ist auch meine María da gewesen. Habe dann nicht einmal was Bedeutendes gehabt mit meinem Freund einfach zusammen zu sein weil irgendwieich habe gar kein Bock, mit ihm uhmm- und dann später als eben [Marías] Familie zurück nach Spanien gegangen sind, da habe ich gesagt 'Okay, gut, dann heirate ich halt.'

And later I met the ex-husband and then [...] we were together for two years. [...] And in these two years my María was also here. I didn't even have something meaningful with my boyfriend, just being together because somehow- I have no desire with him to uhmm- and then later when [María's] family went back to Spain I said 'Okay, fine, I'll marry.'

-Teresa Ruiz

By marrying her boyfriend despite her obvious sexual disinterest and lack of devotion, she not only foreclosed her fear of another bout of social isolation but also gave in to the pressure exerted on her by her family: "Und dann eben wahrscheinlich habe ich das gemacht was meine Familie wollte: (lahm) dass ich endlich heirate und Kinder habe und dann habe ich gesagt doch ist gut, dann machen wir halt." - "Probably I did what my family wanted: (lamely) that I would finally marry and have kids and then I said fine, that's what we'll do." However, soon after moving in together after the wedding, Teresa Ruiz' husband turned what she termed "primitive." He showed vehement jealousy at his new wife's higher income and eventually attempted to forbid her from continuing school: "Dann hat er mir wirklich wollen fast meine Freiheit rauben, da habe ich gedacht 'Spinnst du eigentlich?,' ich bin wirklich von Kuba weggegangen weil ich eben versucht [habe] meine Freiheit auch zu bekommen, also entschuldigung, nein, ohne mich. Ohne mich" - "Then he really almost wanted to rob my freedom from me, then I thought 'Are you out of your mind?' I mean, I left Cuba because I was also trying to, well, get my freedom so excuse me, no, count me out. Count me out."

The divorce lasted a year, during which Teresa Ruiz continued to look for intimacy: "Und Teresa weiterhin aufder Jagd (lacht) - nach Männern, damals noch Männer. Und einer nach dem anderen [...] aber gar nicht mit Liebe zu tun [...] bis ich Angela kennen gelernt habe. Meine 
Freundin." - "And Teresa was back on the prowl (laughs) - after men, back then, still men. And one after the other [...] but nothing at all to do with love [...] until I met Angela. My girlfriend." Teresa Ruiz and Angela Hieber met at work: Angela, aged seventeen, was one of Teresa Ruiz' trainees at a retirement home and soon developed a crush on her tutor. They became best friends: Angela Hieber supported Teresa Ruiz throughout her vicious divorce, and Teresa Ruiz told her friend everything about her various affairs with men. At this time women were still "out of the question" for Teresa Ruiz:

Damals kamen für mich die Frauen nicht in Frage. Du kann dir nicht vorstellen die Einstellung die ich gehabt habe von Lesben. [...] ]etzt überleg ich mir das wirklich, echt krasse Vorstellungen die ich gehabt habe von-von-überhaupt von Homosexuelle weil eben das in Kuba ein Tabu ist. Immerhin von Schwulen wird noch geredet aber von Lesben? Die existieren gar nicht. Es gibt schon bestimmt Lesben in Kuba, Kubanerinnen, aber ich? Sicher nöd! Jesses näi! Das war meine Einstellung, wirklich krasse Einstellung. Also nicht mal 'Okay..., nää, nix rein gar nüt u nix.

Back then women were out of the question for me. You cannot imagine the attitude I had towards lesbians. [...] Now I really think about it, really incredible ideas that I had about- about- about homosexuals in general because in Cuba this is a taboo. [A]t least, gay men are talked about, but lesbians? They don't even exist. I'm sure there are probably lesbians in Cuba, Cubans, but me? Of course not! Jesus no! This was my attitude, really incredible attitude. Not even 'Okay..., nope, nothing at all whatsoever. -Teresa Ruiz

With respect to the visibility of queer people in her home city in Cuba, Teresa Ruiz was only aware of one gay (men's) bar and the circulation of vulgar jokes and mischievous gossip about gay men. By contrast, there was a complete silence around lesbian desire, and lesbians and lesbian spaces were invisible. Lesbians did "not exist." As Teresa Ruiz' above statement exposes, however, this complete silence and invisibility was paradoxically coupled with a distinctly negative (non-)image of lesbians, a stigma that transpires from the interstices of the collective denial, substantiated in Teresa Ruiz' own repulsion and dissociation from anything to do with same-sex desire among women. It is in this elusive but pervasive silence/repulsion that Teresa Ruiz later grounds her inability to identify as a lesbian when coming of age.

Such a deep silence around, and invisibility of, female same-sex desire, practices, relationships, and identities, paradoxically paired with a diffuse and negatively connoted knowledge of their existence, occurred across accounts. Several interviewees had to grapple with this "tabuisierte Tabu" - "tabooed taboo" (Ramiza Salakhova) when growing up in their home countries. Charlotta Sembiring's following statement is a disturbing example of this paradoxical space that marks the taboo around female same-sex desire:

And I learned about sexuality more in Holland. Because in Indonesia, I didn't have idea about 'lesbian,' right? Even the word lesbian - nobody talked to me about that. [...] That's with my lesbianity as well, when I was in Indonesia, I [was] already married, I was falling in love with a girl from the church, I'm Catholic, officially here in Switzerland I pay [church taxes] (grins). So everybody knew actually, we were like, loving each other. We were acting like lovers but nobody was able to - or daring to - tell me. And 
me I just didn't see it, I mean I was married, then she also had her boyfriend, I knew her family, I was visiting her family, staying with them, and even the mom was seeing us kissing. But [...] nobody just say 'Hey, what are you doing, are you lesbian?' No. It was really a shock for me, and you know, knowing that later, when I was in Holland likebecause yeah, if someone was able to say that to me then I could act on that. You know because I was really comparing my marriage with this woman, but I didn't really have the chance and neither for her, because we were just like, everybody was accepting us like good friends, because in Indonesia it's common if you touch, holding hands, hugging, between women it's just normal.

-Charlotta Sembiring

The utterance "Nobody was able to - or daring to - tell me" cristallizes the paradox of the taboo around female same-sex desire: The term 'daring' carries with it Charlotta Sembiring's reproach that the people around her deliberately kept information about her sexuality from her, be it for fear of offending her, of losing face, or of social sanctions. Quite differently, 'not being able' signifies that people effectively did not have the words or concepts for naming or even recognizing the nature of the two women's connection. In either case, through her environment's failure to call her attention to the possibility of considering same-sex desire as a fully valid alternative to heterosexuality, Charlotta Sembiring retrospectively feels bereft of the possibility to make a conscious choice with respect to her sexual orientation and her way of life. Her mimicry of the reaction she never got - "Hey, what are you doing, are you lesbian?" - indicates that in exchange for being presented with a concept to make sense of her feelings she would have accepted stigmatization, the evil twin attached to visibility in connection with discriminated minoritarian identities. Ironically, it is thereby exactly this broad social acceptance of very close and - within limits - also physical friendships among women that nips the visibility of 'serious' female same-sex desire, sexual acts, and relationships in the bud, and reinstates the heteronormative order.

Hence, looking back at their younger Selves from the perspective of now self-conscious lesbians, Teresa Ruiz and Charlotta Sembiring explain the fact that they did not recognize their same-sex desire earlier with the taboo around female same-sex desire in their families and circles, which rendered it impossible for them to understand their feelings in terms of same-sex desire. ${ }^{1}$

A few months into their friendship, on Angela Hieber's initiative, she and Teresa Ruiz engaged with each other erotically one night. Overwhelmed and confused by her own desire, Teresa Ruiz rebuffed her friend: "Es war wirklich ein Kampf. [...] Und dann habe ich gesagt 'Nein. Ich bin nicht lesbisch. [...] Ich bin nicht lesbisch, ich stehe aufMänner.' [...] Aber die körperliche Anziehung war waaahnsinnig, das habe ich wirklich noch nie so stark gefühlt, wirklich noch nie" - "It was really a fight. [...] And then I said "No. I am not lesbian [...] I am not

1 As discussed in Chapter 3.3.4, and as emerges in interviewees' narratives here, the invisibility and silence of female same-sex desire are ambivalent. While advocating for the acknowledgement of non-Western configurations of desire that are not organized around an identity and a coming out, David A. B. Murray (2011) warns against romanticizing silences and invisibilities around same-sex desires as they often remain related to homophobias. 
lesbian, I fancy men.' [...] But the physical attraction was iiimmmense, I have never felt this as strongly before, really never." Unable to ignore her awakened desire, Teresa Ruiz eventually yielded to Angela Hieber's prompts and agreed to become involved with her, under the strict condition that no one learn about the nature of their relationship. Nevertheless, they moved in together. One and a half years into their secret relationship, Teresa Ruiz realized that she wanted to have children. Despite Angela Hieber's pleas, it was beyond Teresa Ruiz' imagination to have children with a woman, and she left her partner - although from Teresa Ruiz' point of view they had never really been together in the first place.

Und dann habe ich sie verlassen. Habe gesagt 'Nein, wirklich nicht.' Und es ist mir wirklich so schlecht gegangen wirklich schlecht schlecht schlecht, und dann habe ich müssen zum Psychologen gehen und das Ganze wirklich anzuschauen. [...] Und dann trotzdem habe ich halt dann mit einem Mann etwas angefangen, aber ich habe nicht mal können mit dem schlafen, he, das chasch vergässe, he? [...] Das mit dem Psychologen hat mir wirklich sehr viel geholfen, und jetzt kann ich auch sagen 'Ich bin Lesbe.' [...] also ich bin keine Männerhasserin, das überhaupt nicht, aber ich möchte wirklich nicht mehr eine Beziehung führen mit einem Mann. Deshalb fühle ich mich auch als Lesbe.

And then I left her. I said 'No, definitely not.' And I felt so bad really bad bad bad and then I had to go to the psychologist and to really look at the whole thing. [...] And then in spite of that I started something with a man, but I couldn't even sleep with him, eh, you can forget about that, you know? [...] The thing with the psychologist really helped me a lot, and now I can also say 'I'm a lesbian.' [...] well I'm not a man-hater, not at all, but I really don't want to be in a relationship with a man anymore. This is why I also feel as a lesbian.

-Teresa Ruiz

In this key sequence, Teresa Ruiz moves from rejecting her same-sex desire to identifying as a lesbian. Her statement grounds the homophobia she has been directing at herself in the circulating stereotype of the man-hating lesbian, from which she explicitly distances herself. Facilitated by a psychiatrist, Teresa Ruiz learns to acknowledge her same-sex desire and to frame it in the context of a positively valued homosexual identity. The account conveys a sense of arrival and homecoming. As Teresa Ruiz later says to a friend: "Jetzt weiss ich was gut ist" - "Now I know what's good." Importantly, however, the formulation of the lesbian identity becomes possible through the facilitation of a psychologist. Teresa Ruiz' awakened desire for the same sex hence becomes forged into a 'Swiss' lesbian identity through the thoroughly Western institution of psychology (see below).

\subsection{3 "I really am a lesbian of Switzerland!": Cultural and Sexual Identity}

Just before our second interview, Teresa Ruiz had made a new acquaintance. Visibly agitated, she relates the story of Sophia Cruz, another Cuban woman who also lives in the Basel area. Sophia Cruz grew up in a city that has a reputation for being the most conservative city in Cuba, and yet from her early teens she had been a member of a 
thriving underground lesbian community there. "She was really, in Cuba, a lesbian." Teresa Ruiz is incredulous as she describes a coming of age that could not have been more different than her own, involving wild parties, promiscuity, and even a specifically Cuban lesbian chat site. "Das wusste ich nicht dass es überhaupt so etwas gibt in Kuba. [...] Und wie sie sich einfach so, richtig, verhalten hat in Kuba und dass es auch Frauenpartys gibt, und es ist wirklich ein Weltbild das nicht geht in Kuba" - "I didn't know that there is such a thing in Cuba. [...] And the way she, really, behaved in Cuba and that there were women's parties, and it is really a worldview that doesn't work in Cuba."

Teresa Ruiz is both fascinated and shocked by Sophia Cruz' tales, which she explains in cultural terms:

Aber die Geschichte die sie mir erzählt hat ist so-also ich sag-ich bin wirklich eine Lesbe von
der Schweiz. Absolut. [...] Aber weisst du was ich am Ende gesagt habe? Da habe ich gesagt
'Ich bin froh dass ich mich Lesbe gemacht habe da in der Schweiz' (lächelt). Weil irgendwie-
also so wie sie es mir erzählt hat, würde überhaupt nicht mit mir passen. [...] Weil eben, alles
mit alle sind und ich weiss es nicht, gibt kein Konzept von Treue und ja, wenn dir etwas gefällt
obwohl du eine Beziehung hastja ho halloo?! Das würde überhaupt nicht mit mir passen. Und
ja, sie ist eine, die ü.b.e.r fünfzehn Frauen gehabt hat! Also entschuldigung, kannst du dir das
vorstellen?

But the story she told me is so- well I say- I really am a lesbian of Switzerland. Absolutely. [...] But do you know what I said in the end? I said 'I'm glad that I have made myself lesbian in Switzerland' (smiles). Because somehow- well the way she told me, it would not be like me at all. [...] Because well, everyone is with everyone and I don't know, no concept of fidelity and yes, if you like something even though you have a relationship, yes ho helloo?! That would not be like me at all. And yes, she is someone who had o.v.e.r. fifteen women! Well excuse me, can you imagine that?

-Teresa Ruiz

Two dichotomous figures of the lesbian emerge here: the promiscuous and philandering 'Cuban' lesbian exploring her same-sex desires in rampant semi-legal underground parties (paradoxically oddly reminiscent of the earlier Teresa Ruiz on the "prowl" for men) whom Teresa Ruiz distances herself from; and, on the other hand, the contained, faithful 'Swiss' lesbian Teresa Ruiz identifies with now, who lives in a stable and monogamous relationship, who conforms to traditional gender roles by establishing a nuclear family with a clear-cut division of labor, and who generally leads an orderly, rather conservative life.

Sophia Cruz' tales shatter the image Teresa Ruiz had constructed of her home city in the first interview, in which lesbians did "not exist." As pointed out above, Teresa Ruiz' explanation as to why she had not developed a lesbian identity in Cuba hinged on the seemingly objective 'fact' of the invisibility of lesbians there. Sophia Cruz' tales expose this 'fact' as subjective experience, uncovering Teresa Ruiz' inability to see lesbians in Cuba as an effect of her biography and social positioning instead: due to illness, Teresa Ruiz spent a great deal of time at home, embedded in a family in which female same-sex desire was silenced and therefore unavailable to her as a concept with which to frame her developing sexuality. 
What is more, Teresa Ruiz' reaction to Sophia Cruz' revelations is highly ambivalent: In her incredulity, she spontaneously expresses regret about having "missed out" on something, wondering what could have been had she not been subject to long bouts of illness but instead attended one of the sports schools her sisters went to, which according to Sophia Cruz were veritable lesbian strongholds. Then she immediately corrects herself, repeating this would not have been "like her," concluding that exploring her same-sex desire in the lesbian underground in her city would have forced her into practices she does not feel would have been in line with her personality at the time. But her curiosity remains sorely piqued, and she is burning to go to Cuba and see with her own eyes the lesbian spaces described by Sophia Cruz, of which she was completely unaware when growing up, but which according to Sophia Cruz do in fact exist.

Sophia Cruz' narrative fundamentally destabilizes the way in which Teresa Ruiz had previously made sense of her sexual biography - namely, that she had not identified as a lesbian in Cuba because there were no (visible) lesbians in the social environment in which she grew up. This exposes how central a stringent account of how one has come to identify as a lesbian is to the lesbian identity. Moreover, it is not only Teresa Ruiz' conceptualization of the development of her sexual identity in the past that is called into question by the figure of the promiscuous 'Cuban' lesbian, but also its development in the future:

'Das hast du im Blut! Das wird noch kommen!' [sagte Sophia] Da habe ich [Teresa] gesagt 'Nein' (streckt den Finger hoch und winkt ihn hin und her) 'Sicher nöd, ich bin seit fünfJahren mit einer Frau, mit die Frau bin ich glücklich und die Frau bleib ich.'

'You have this in your blood! It'll come!' [said Sophia] Then I [Teresa] said 'No' (lifts her finger and wags it left to right) 'Definitely not, I have been together with a woman, I am happy with this woman and I will stay with this woman.'

-Teresa Ruiz

Sophia Cruz' quip places a dormant Cuban (promiscuous) lesbian within Teresa Ruiz, an idea by which she feels threatened. No matter whether Sophia Cruz understands "blood" in terms of genetics or upbringing, her jibe exposes the assumption that an individual cannot escape the way she is shaped by the environment she grew up in, and that the kind of lesbianism Sophia Cruz herself lived in Cuba naturally grew from how Cubans essentially are and how Cuba is - there seems to be no other way in which a Cuban can be a lesbian. The insinuation renders Teresa Ruiz' adopted 'Swiss' lesbian identity - as ethnicized (i.e. white) as its Cuban counterpart - brittle and superficial because Teresa Ruiz assumed it in a culture that is here postulated as incompatible with her own cultural background (or genes). Instead of understanding their divergent sexual biographies in terms of personal circumstances (such as Teresa Ruiz' illness) or personal characters, choices, and preferences, the two women hence frame the meeting of their respective sexualities in terms of a cultural clash, reiterating essentializing ideas about how culture, ethnicity, and sexuality mutually constitute each other.

This juxtaposition of two seemingly contradictive sexualities/cultures becomes even more complicated when adding the fact that despite Sophia Cruz' own non-ambiguous youth, her lesbian identity has remained precarious: According to Teresa Ruiz (Sophia 
Cruz declined to participate in the study), Sophia Cruz has been living with a husband and children in Switzerland for a few years, but is now in the process of divorcing her husband after realizing that she does not want to live with a man anymore. This suggests that the two women's conditioning (such as e.g. the pressure to get married and have children) and biographies are in fact more closely related than their playful dispute might suggest.

\subsubsection{Learning to Be a 'Good Lesbian': Sexuality, Citizenship, and 'Integration'}

The vehemence with which Teresa Ruiz both asserts her 'Swissness' and rejects the insinuated dormant 'Cubanness' of her lesbianism can be addressed by reading the narrative of how she came to identify as a (Swiss) lesbian through her integration narrative. At a specific point in her life, Teresa Ruiz explicitly resolved to "integrate" into Swiss society, and the strategies she devised to reach this end crucially structure her narrative, which is largely the story of a successful assimilation project. Her account associates the eventual success of her 'integration' with three particular developments: learning the Swiss language, re-launching her professional career, and becoming a lesbian. In other words, not only Teresa Ruiz' personal preferences are called into question in her discussions with Sophia Cruz, but also her sexual citizenship in Switzerland and thus the success of her migration project. For Teresa Ruiz, learning to be a 'good lesbian' is a component of becoming a 'good Swiss citizen.' This mutual constitution of normative sexual identity and citizenship is the focus of the following discussion.

I use the expression "learning to be a 'good lesbian" with deliberation. As the analysis of the biographical material - also taken from stories other than Teresa Ruiz' - presented in the following suggests, assuming a 'Swiss' lesbian identity entails both an intellectual and an emotional effort that includes the negotiation of negative lesbian stereotypes, the positive reclamation of a lesbian identity, and the revision or dismissal of previous sexual practices and relationships. These negotiations expose the figure of the lesbian as a product of dominant discourses around sexuality in Switzerland - a set of ideas, practices, preferences, tastes, and beliefs regarding sexuality that systematically constructs the lesbian subject, her place in Swiss society, and the positions from which she can(not) speak.

Becoming a lesbian was often enabled by embodied 'catalysts' such as institutional and private facilitators/enforcers/teachers who drove interviewees' process of becoming a 'good lesbian,' as well as through the sexualization of everyday spaces and places. In Teresa Ruiz' case it was an institutional catalyst, her psychologist, who led her to acknowledge her same-sex desires and eventually to her identification as a lesbian - "the psychologist really helped me a lot, and now I can also say 'I'm a lesbian." This account reveals that psycho-therapeutic practice does not merely act as a vehicle for the homosexual patient to reach the point where she is able to acknowledge the 'fact' of a preexisting lesbian identity, but instead emerges as the very site of production and perpetuation of bounded sexual identities. Teresa Ruiz' lesbian identity is therefore not predetermined, but rather comes into being in the very moment she states "I'm a lesbian" on the couch. 
Other interviewees themselves frame their experiences undergoing psychotherapy as a milestone in their process of integrating into Swiss society, because they perceive psychotherapy to be a fundamentally Western phenomenon and practice per se. As Charlotta Sembiring remarks, "we actually didn't need any psychiatrist [in Indonesia], because we have our friends." To her, having had to go to a professional to process her nervous breakdown is evidence of the advanced fragmentation, isolation, and individualization in European culture. Undergoing psychotherapy hence functions as a rite of passage in one's transformation into a Europeanized subject that thinks of herself, her social environment and her place in it in highly specific ways. ${ }^{2}$

A second institutional site of production of the 'good lesbian' that has emerged from the narratives is social scientific research, with myself in the position of the researcher as its catalyst. Several interviewees pointed out that discussing their sexuality in the interviews had helped them to 'clarify things.' As Beatriz Krais said at the end of our first interview:

$B K$ : Ah, j'étais nerveuse [de l'entretien] pour rien.

TB: Tu étais nerveuse, oui c'est parfois les gens ils pensent qu'ils peuvent dire des choses qui sont fautes.

BK: Non non mais c'était même pas ça, c'était justement le fait peut-être de devoir parler de choses qui-ouais qui maintenant sont plus facile mais c'est pas-je suis pas encore-je suis bien dans ma vie tout ça, j'accepte tout, mais des fois c'est quand même difficile de parler, alors j'avais juste une petite appréhension de ce côté là (rit).

BK: Ah, I was nervous [about the interview] for nothing.

TB: You were nervous, yes sometimes people think that they can say things that are wrong.

BK: No no but it was not even that, it was just maybe the fact to have to talk about things that-yes that are now easier but this is not- I'm not yet- I'm good in my life and everything, I accept everything, but it is sometimes still difficult to speak, this is why I was just a little bit apprehensive concerning that (laughs).

-Beatriz Krais

Beatriz Krais had not talked about her homosexuality openly before and consciously exposed herself to this interview situation to process her continued unease vis-à-vis her homosexuality. At the end of the second interview she explicitly framed her participation as therapeutic:

2 A disturbing perspective on racialized Others undergoing psychotherapy in Switzerland is further the deep historical implication of the discipline and institution of psychology in the production, control, and destruction of these very racialized Others. As Graham Richards notes: "[How Psychology has historically engaged with the 'race' issue] is a central aspect of the history of 'race' and racism, for it has largely fallen within Psychology's province to address such matters as whether 'race differences' of a psychological kind exist, the nature of racial attitudes and 'race prejudice, and, more recently, the extent to which unacknowledged ethnocentrism distorts theory and practice in the human sciences" (Richards 2012:xiii). Psychology as a discipline and institution and psychoanalytical practice in Switzerland remain to be analyzed from a postcolonial/critical race perspective. 
BK: [Concernant sa participation dans la recherche :] C'était un plaisir (rit). C'était une bonne thérapie.

TB: Une thérapie?

$B K$ : De parler, ça fait du bien je trouve (rit)

TB: Tu pensais que c'est comme une thérapie?

$B K$ : Non non non non, mais je dis ça fait du bien de parler [...], quand on parle que ce soit avec Josephine [son partenaire] ou avec ma famille ou avec les amis, je trouve qu'y a pas la même impartialité, je dis le fait de parler à quelqu'un qui tu ne connais pas, alors t'as pas d'attentes, t'as pas de jugement, comme ça alors ça fait du bien, ouais, de parler de tout ça comme ça. [...] Voilà quoi ça fait une bonne thérapie. Tu devrais faire psychologue (rit).

BK: [About participating in the research] It was a pleasure (laughs). It was a good therapy.

TB: A therapy?

BK: To speak, this feels good I think (laughs).

TB: You thought it's like a therapy?

BK: No no no no, but l'm saying it feels good to speak [...], if you speak be it to Josephine [her partner] or with my family or with friends, I think that there is not the same impartiality, I'm talking about speaking to someone you don't know, you don't have any expectations, you don't have any judgment, like that that feels good, yes, to speak about everything like that. [...] So this made a good therapy. You should become a psychologist (laughs).

-Beatriz Krais

This shows that the research interview setting also acts as a platform for participants to practice speaking about homosexuality, which Beatriz Krais still feels self-conscious about discussing in other contexts. Narrating her story serves her to further understand, express, and strengthen her self-conception as a lesbian, also actively working on what she perceives as a 'dent' in her lesbian identity, that is, her continued reticence to speak openly about her sexual orientation. From this, the 'coming out' once more emerges as a vital and integral part of what it means to be a 'good lesbian.' The effect of this research thus remains ambivalent: As a platform for self-reflection and acknowledgment, it sometimes seems to have had an empowering effect for some participants. At the same time, it also represented a site for the reproduction of sexual norms (and hence also processes of othering). This was clearly influenced by my own positionality as a white Swiss lesbian. Towards the end of the interviews, I was frequently asked questions about my own 'coming out' story and life situation, and my answers often served as a point of reference against which interviewees then positioned themselves.

That being said, becoming a 'good lesbian' was not solely tied to human catalysts but also occurred through the sexualization of everyday spaces and places. Charlotta Sembiring frames Amsterdam, the first place she lived after emigrating from Indonesia, as an all-encompassing homosexual learning space. In the following excerpt she explains why she believes she learned more about (homo)sexuality in Holland than in Indonesia:

So in Holland [...] l'd see people meeting: lesbian couples, gay couples, hetero people. There are so many books in the public libraries. You see movies. And cafés. [...] It was 
just really great, even though at that time I didn't fall in love with a woman, but it's so much space for learning in this particular spot. [...] I learned really a lot there, also for myself, my sexuality, my life, and-also from the study, so that's how I think I fall in love with Holland.

—Charlotta Sembiring

A 'lesbian flâneur' (Munt 1995), Charlotta Sembiring absorbs images, texts, and places, and revels in the possibilities opening up before her. An excited traveler, she gapes at the cultural novelty, still reluctant to engage but already playing with the thought. The figure of the lesbian is conveyed by the assemblage of the spaces and places making up Amsterdam, saturated with sexual innuendo, which allow Charlotta to let herself be surprised by the sight of a women's café or a lesbian couple kissing in the streets or, alternatively, to actively look for lesbian books or movies.

These ways in which institutional spaces and practices, human catalysts, and sexualized inscriptions of public spaces and objects coagulate to produce the field that enables/pressures queer migrants to become 'good lesbians' will be revisited from different perspectives throughout this study. Notably, this mechanism will be viewed from the perspective of asylum procedure (Chapter 8), in which coercion is tied to the process of becoming a lesbian, and in Chapter 5.2.1, which shows that even for women who already identified as lesbians or with another same-sex sexual identity when coming to Switzerland, becoming a 'Swiss' lesbian is a prerequisite for social inclusion.

\subsubsection{Incongruent Desires and Genders}

In Cuba, Teresa Ruiz led an entirely heteronormative life. She lived and identified as a heterosexual and did not miss anything. By contrast, other interviewees who did not have a 'consolidated' same-sex sexual identity before they emigrated experienced a sense of incongruity and isolation up to the point of their departure, often without ever having engaged in sexual relationships with other women prior to migrating. Their narratives tie these feelings to a sense that their desires were 'wrong,' but also to a sense of confinement by narrow and poorly-fitting gender roles. The desire to explore these more or less vague feelings of alienation was sometimes one of the principal reasons why interviewees emigrated. From their current perspective, homosexuality serves as an explanation for this sense of difference, which is now understood to have been significantly aggravated by the lack of queer role models available to them when they were coming of age.

A close reading of how these interviewees explain their sense of difference allows us to develop an understanding of how they conceptualize their (homo)sexuality now and how they perceive their sexuality to have changed through migration.

As Beatriz Krais explains why she left Brazil as a young woman:

Je me suis toujours sentie un peu différent de mes copines au Brésil, c'est vrai que j'étais jamais très à l'aise. [À] l'époque je pensais pas comme ça, [mais] maintenant je me dis que je suis partie du Brésil pour venir ici et vraiment découvrir mon homosexualité, pouvoir être à l'aise avec ça. Mais à l'époque je me sentais pas-justement j'aimais beaucoup le sport alors j'étais tout le temps en training et en baskets; mes copines elles préféraient apprendre à se maquiller à se coiffer 
(petit rire) et ça c'est vrai que ça faisait vraiment un gros décalage. Et je pense que c'est aussi pour ça-pour essayer de me lâcher dans le sens de découvrir toutes ces choses-que je voulais partir du Brésil.

I always felt a little different from my peers in Brazil, it's true that I never really felt at ease. Back then I didn't think like that, but now I'm telling myself that I went away from Brazil to come here and really discover my homosexuality, to be able to feel at ease with this. But at the time, I didn't feel- I just liked sports very much so I was training all the time and wearing sneakers; my [female] friends preferred to learn how to put on make-up and to do their hair (small laugh) and it's true that this really produced a big discrepancy. And I think that it's also because of that - to try and to cut myself loose in the sense of discovering all these things - that I wanted to leave Brazil.

-Beatriz Krais

It is through the lens of a self-conscious post-migration lesbian identity that Beatriz Krais makes sense of her feelings of misplacement and exclusion when growing up. It is only after falling in love with a woman in Switzerland ("la première femme que je suis tombée amoureuse et que j'ai nommé 'Je suis amoureuse" - "the first woman I fell in love with and labelled as 'I'm in love") that things she had long felt "commençaient à avoir des noms" - "started to have names."

Beatriz Krais' previous sense of unease is grounded in narrow gender roles and bodily visual norms and performances. As an adolescent, she liked sports, preferred to dress casually, and felt baffled by her peers' stereotypically feminine fashion interests. Her discomfort with these gendered expectations now serve Beatriz Krais as proof that she has in fact always been a lesbian but needed physical and cultural distance from Brazil to be able to "name" her inclination. In other words, in the European lesbian identity she has found a social home that allows her to align her desires, bodily needs and gendered performance with a bounded social identity. In other areas of life, her migration narrative is also framed as a story of réussite - achievement. In the face of the adversities and the racisms inherent in Swiss immigration procedure, Beatriz Krais has managed to establish a good life by studying, obtaining a respectable job as a sports instructor, establishing a fulfilling relationship with her Swiss partner, and installing herself in a spacious apartment. The enormous amount of work and energy that have gone into accomplishing these things are a great source of pride to her, and this is key to her narrative. She has arrived: "C'est vrai que je me sens bien" and "'est vrai que je me suis bien intégrée" - "It's true that I feel good" and "it's true that I have integrated myself well," she states. Within this integration story, coming to terms with her dissident sexuality and assuming a lesbian identity are framed as central milestones.

The process of acknowledging that her attraction to women is an integral part of who she is has been arduous. Rehearsing Diane Fuss' observation (1991) that to come out means to simultaneously call into being a closet, being able to give "names" to things long felt, was immediately paired with repulsion and shame:

Au début c'était difficile, j'avais honte, bon je peux même pas dire honte de quoi, c'était honte de tout quoi, honte de moi, j'ai dit 'C'est pas normal je dois pas,' honte que-justement par rapport à ma famille j'ai dit 'Alors comment je fais,' honte par rapport à tout quoi-j'ai dit 'Comment si 
les gens ils découvrent,' ouais c'était une honte générale. Oui j'avais honte, oui. J'ai mis du temps à être à l'aise et pouvoir dire 'Oui ma copine, ma compagne' ou quelque chose comme ça, j'ai mis du temps oui.

In the beginning it was difficult, I was ashamed, okay I can't say ashamed of what, I was ashamed of everything, ashamed of myself, I said 'It's not normal I can't,' ashamed that- concerning my family I said 'Well how do I do this?' ashamed of everything, I said 'What if people find out,' yes it was a general feeling of shame. Yes, I was ashamed, yes. It took time to be at ease and to be able to say 'Yes my girlfriend, my partner' or something like that, it took time, yes.

-Beatriz Krais

Augusta Wakari's tale also accords a central place in her narrative to the extent to which migration has enabled her to reflect on and renegotiate her gender positionality, but offers a different perspective on the issue. When living in Indonesia, Augusta Wakari occupied the masculine role in the relationships she had with women. Although in Indonesia, like in all of Asia, a host of identities exist that are organized around female masculinities, Augusta Wakari was not aware of any of these descriptors when she came of age. ${ }^{3}$ She states that generally "Indonesia neeeever gave you a lesbian thing, never! NEVER! see those kind of thing until I was I don't know how old but- big enough, I think yeah high school or something like that." This was despite the fact that she had her first serious sexual relationship at the age of ten with a woman twice her age. As she grew older she was increasingly pushed into the masculine role in relationships, while maintaining parallel "fake" relationships with men because "society wants me to be with men."

They couldn't picture two women- now they picture me as a man! The people. They even call me instead of sister a brother! So they really picture me as a man. And also instead of saying l'm beautiful they will say l'm handsome. [...] They just still don't know how to put two women together. [...] Instead of saying that I'm the wife they will say that I'm the husband you know those kind of thing. [...] They just don't know how to address that, you know?

-Augusta Wakari

Augusta Wakari retrospectively diagnoses the unthinkability of female same-sex desire in what she refers to as "Asian" contexts to have been so profound that it was easier for people to change a person's sex (sic) than to acknowledge female same-sex desire in its own right. Looking back, Augusta Wakari states that this distinctly masculine role had not come to her naturally:

It is quite tiring because I am not a man! If I have to be like man all the time, especially in Asian relationship, a man have to carry, a man have to do this, a man have to do the

3 Female same-sex sexualities in Indonesia are comparatively well researched (e.g. Blackwood 2010, see also Blackwood 2005, Boellstorff 2005 and 2007, Murray 2001, Offord and Cantrell 2001, Sulandari 2009, Wieringa 2006). This body of work also describes a variety of identities related to female masculinities, which differ significantly across regions and class. 
hard work man have to tatata- I need a pampering as well! I need to be taken care of as well you know? [...] In Asian way the man work and the women stay at home and do all the work, but I am not like that. I always cook, I always take care of the house so-. And in sex it's exactly like that. You know (laughs). At the end I ignore what I need. [...] But they [her girlfriends in Indonesia] just don't know, most of them they just don't know how to do it. And at the end they're not ready for that and I'm scared if I tell them what to do, see?

-Augusta Wakari

For Augusta Wakari, the masculine role she performed in same-sex relationships was hence assigned rather than chosen. The narrow interpretation of female masculinity she was expected to inhabit left her unable to articulate her more complex gender positionality and sexual desires and regulated her most intimate practices. This left her actual preferences, needs, and weaknesses unacknowledged beneath a shell of appointed masculinity.

Like the two other masculine Southeast Asian participants in this study, Augusta Wakari describes her Asian girlfriends as 'heterosexual': "And all my girlfriend are hetero. Normal in Asia. It's normal. You can only have hetero women as your girlfriend." According to these participants' accounts, girlfriends identifying as heterosexual ranked their relationships to masculine women inferior to relationships to 'real' men but accepted masculine women as makeshift lovers until the "right guy" turned up (Jasmine Sieto), or until they considered it time to transit to their designated role as heterosexual wives and mothers (Siti Mohd Amin). Augusta Wakari's statement that "you can only have hetero women as your girlfriend" at the same time raises the question who "you" is, and how "hetero" is to be defined. In her narration "you" points to women who assume - or are assigned - a masculine role, and, importantly, who conceptualize their same-sex desires as an intrinsic and immutable part of who they are. This is contrasted with the "heterosexual" girlfriends - feminine women who frame their same-sex relationships as a temporary arrangement before pivoting into the inevitable heteronormative biography assigned to them. ${ }^{4}$ Importantly, designating feminine partners as "heterosexual" forecloses a full validation and originality of same-sex intimacy while at the same time emphasizing the masculine partner's commitment, which is rendered vulnerable and inferior. ${ }^{5}$

This is the backdrop against which Augusta Wakari frames her migration as a narrative of sexual self-realization and recovery, juxtaposing the 'Asian' hetero/homonormativity in which she grew up with 'European' queerness and liberalism. As an adolescent in Indonesia, she was the troublemaker in her family. The question of what she was going to do with her life if she was not allowed to express and act on the feelings she had for women nagged at her, and she wondered whether she was eventually going to have to

As Yuenmei Wong (2012) points out in reference to the Malaysian context, these women sometimes also identify as bisexual.

5 Augusta Wakari's experiences resonate with Alison Murray's observation that in Indonesia "in the simple terms of popular magazines, the butch (sentul) is more than 50 percent lesbian, or incurably lesbi, while the femme (kantil) is less than 50 percent lesbian, or potentially normal" (Murray 2001:169). 
follow "what they want me to be." In their helplessness, her parents blackmailed her girlfriends and at the age of twenty sent her to Switzerland to separate her from her girlfriend. After three years of professional training, Augusta Wakari decided to stay in Switzerland: "I love my freedom," she assesses, while in Indonesia "you cannot be yourself."

Augusta Wakari's assertion that the masculinity she performed in Indonesia had been imposed upon her rather than freely chosen gains clarity in the context of her relationship with her Belgian partner, Joëlle Bregnard, who emerges as a catalyst in Augusta Wakari's process of becoming a 'good lesbian.' The attendant process of (un)learning reaches into the most intimate spaces. In the following quote, Augusta Wakari speaks about sexual practices:

And I'm ignoring myself so long, what I need, what satisfied me, and I learned slooowly with Joëlle again. She's very passionate and she keeps on te[lling me] 'Hey, we have the same right! Hey we have the same- in everything! You don't have to do more than me!' [...] And I start learning-start [at] the beginning again: okay. But still she has to remind me all the time.

-Augusta Wakari

This statement points to a shift in Augusta Wakari's gender positionality from stereotypical masculinity to one that is more individual and complex. On the one hand, she continues to understand herself as masculine in many ways. As she says to her partner with regard to her participation in a drag king workshop: "Why should I pay eighty franks just to be like I already am?" On the other hand, she experiences it as a relief to be able to let go of the pressure to conform to gender and sexual practices that she has come to recognize as imposed and damaging.

Her process of unlearning does not remain restricted to sexual practices and gender roles but extends to other aspects of her relationship with her partner, especially trust. Having been left for men by several of her 'heterosexual' feminine partners in Indonesia, she finds it very hard to trust a partner:

Nobody ever show me before that 'It is okay, you are safe, it is okay to trust.' [...] It is still in a very early stage, but I also explain to her 'Please, I am very sorry because I'm not really good in this kind of thing, you know?' [...] And to trust people it takes really a long period of time for me.

-Augusta Wakari

Although a decade older than her partner, Augusta Wakari clearly positions herself as her partner's disciple, learning from her how to build a stable monogamous relationship, how to trust a partner, how to claim one's rights, and how to become aware of, acknowledge, and act on one's sexual needs. Her narrative frames this as a process of physical and psychological recovery. Importantly, this recovery hinges on reflecting upon and gradually abandoning her former (Indonesian) sexuality. Indeed, the sum of her same-sex relationships in Indonesia are dismissed as unhealthy as Augusta Wakari wipes clean the whiteboard of her sexual experiences and emotional imprints in Indonesia: "I start [at] the beginning again." 
Looking back, the interviewees subsumed under the trajectory "Now I can say I am a lesbian" retrospectively tie their sense of difference and alienation to their sense of having 'wrong' feelings and desires and to the social pressure to adhere to confining gender roles. This sense of alienation is framed as a prominent reason to migrate. Explained by their homosexuality post-migration only, it was often the expectation to perform heteronormative femininities that triggered a sense of incongruity when growing up and coming of age. Some narratives are thereby organized around a rhetoric of discovery, implying that one's homosexuality had always been present but could be "named" after emigration only. Others, like Augusta Wakari, assess that they were trapped in homonormative female masculinities, ${ }^{6}$ which, while corresponding with their self-conceptualizations to some extent, they have experienced as lacking the complexity and flexibility to accommodate all aspects of their personalities.

It is important to note that the trope of retrospective interpretation of more or less vague feelings of misplacement connected to heteronormative gender roles is not unique to queer migrant biographies but has also been described in studies focusing on non-migrant lesbians in Switzerland (Caprez and Nay 2008, Moser 2001). Several of Christina Caprez and Eveline Nay's interviewees relate that they left the rural canton of Graubünden for Zürich in order to explore the roots of their sense of isolation, which in retrospect many of them connect to a sense of confinement with regard to normative gender roles. These narratives of non-(international) migrant women preclude the conclusion that gender roles are necessarily more open and flexible in Switzerland than, for instance, in Asia. Rather, the act of migrating itself enables interviewees to reflect on their personalities and positionalities in terms of gender and sexuality.

\subsubsection{Conclusion}

In the biographical narratives discussed in this sub-chapter, becoming aware of, acknowledging, and naming one's same-sex desires is inextricably linked to the migration process. "My coming out story is the story of my immigration," Adi Kuntsman (2003:300) says, which is a fitting conclusion to draw from the accounts examined here. The "quest for identity" (Knopp 2004), though often confusing and painful initially, is eventually rewarded by a sense of arrival and "homecoming" in the lesbian identity (Fortier 2001, Kuntsman 2005 and 2003). The lesbian identity emerges as a social home that allows for naming one's feelings and aligning one's desires with an acknowledged - if stigmatized - social positionality, which also holds the promise of incorporation into the Swiss lesbian community. Assuming a lesbian identity moreover becomes an avenue to admission into Swiss society at large, leading to stories of achievement and réussite.

At the same time, these accounts show that becoming a lesbian entails certain things, such as the retrospective construction of a stringent biography that logically leads to the lesbian identity. As discussed earlier, Michel Foucault suggested that in

6 Jack Halberstam presents female masculinity as an alternative to male masculinities. In her book of the same name, Halberstam (1998) portrays a wide variety of gender expressions by masculine women ranging from nineteenth century pre-lesbian performances and practices to contemporary drag king performances. 
Western Europe sexuality is something one is rather than does, with the homosexual figure representing "a personage, a past, a case history, and a childhood, in addition to being a type of life, a life form, and a morphology, with an indiscreet anatomy and possibly a mysterious physiology" (Foucault 1978:43). In the process of formulating this biography, interviewees revisit their home places, renegotiating dominant discourses around sexualities 'there' and their own position in relation to these discourses both before and after migration. One recurrent theme in these ruminations is the diagnosis of a profound silence around female same-sex desire and the invisibility of queer women in the social environments in which interviewees grew up, which, as they assess in hindsight, resulted in a lack of role models that rendered it impossible for them to think of their awakening feelings in terms of a valid and original alternative to heterosexual desires, relationships, and identity. As Teresa Ruiz' encounter with Sophia Cruz exposes, this invisibility does not hinge on an effective absence of queer women in interviewees' home countries but on a disciplined vision policed by a taboo around female same-sex sexuality. The narratives retrospectively construct this lack of role models as an explanation for a sense of alienation in adolescence and as a crucial reason why a lesbian identity had not been adopted earlier - implying that the homosexual identity had always been present but went 'undiscovered' until after migration.

Furthermore, identifying as a lesbian entails the adoption of Swiss homonormative values for the advantages that accrue to 'Swiss' lesbians to be realized. This process of becoming a 'good lesbian' is broadly and contradictorily conceived and calls for multiple readings. On the one hand, it is a process of personal development, discovery, recovery, empowerment, and homecoming, driven by subjects who take action in the face of a sense of alienation and discrimination. Queer migrants take on considerable risks and uncertainty by leaving their families and homes behind in order to reinvent themselves in a new and frequently adverse and racist environment. As such, these stories powerfully undercut the stereotype of the victimized and backward female migrant.

On the other hand, narratives about becoming a lesbian in Switzerland also need to be read as processes in which sexualities become disciplined. This is enforced by everyday and not-so-everyday interactions and spaces (such as the institution of psychology or asylum procedure) into which the figure of the 'Swiss' lesbian is inscribed, and which are productive of sexual subjects that are legible to the receiving state and society. This disciplining process not only produces subjects/citizens that are sexualized in specific ways but also racializes Others' sexualities. Swiss and 'other' sexualities are thereby constructed as distinct and irreconcilably dichotomous. The consequence for queer migrant women is that the adoption of a 'Swiss' lesbian identity often requires a simultaneous denigration of, or distancing from, one's pre-migration queer sexuality. Since sexualities are always already racialized and ethnicized, this dismissal also entails a dissociation from one's cultural identity. At the same time, no matter what, the racialized and ethnicized identity assigned to queer migrant women eventually makes it impossible for them to fully embody and assume a normative lesbian identity; Teresa Ruiz' postulated inner (dormant, promiscuous) 'Cuban' lesbianism continues to threaten the supposed (loyal, monogamous) 'Swiss' lesbian identity she is explicitly striving to establish. The image of the promiscuous, unleashed 'Cuban' lesbian is thereby reminiscent 
of McClintock's "porno tropic tradition" (1995) figuring women as the epitome of sexual aberration and excess, against which the Swiss lesbian identity emerges as chaste, contained, and 'civilized.' Likewise, Augusta Wakari needs to shed her sexual past in Indonesia in order to be able to fully embrace the lesbian identity. These movements also mirror Adi Kuntsman's framing of her own immigration "as discovery of lesbian identity, detachment from Russianness, and re-grounding in the Israeli queer community" (Kuntsman 2003:301). Queer homecoming is hence always also reproductive of geometries of power attached to the makings and unmakings of Same and Other sexualities.

\section{2 "I was totally shocked": Differing Sexual (Sub)cultures}

Teresa Ruiz did not entertain same-sex relationships before migrating and understands herself to have become a lesbian in Switzerland. By contrast, Siti Mohd Amin was a member of the queer Malaysian community before emigrating, but has been unable to gain access to the Swiss lesbian community since immigrating. The following discussion focuses on how Siti Mohd Amin has experienced lesbian spaces in Switzerland, an encounter which her narrative frames in terms of (sub)cultural differences between Asian and European female same-sex communities. The analysis continues with an examination of Siti Mohd Amin's (mainly online) transnational ties to the queer Asian community, which paradoxically both propel and counteract her increasing social isolation in Switzerland. Working outwards from her account and considering other cases, the second part of this sub-chapter engages with cyberspace as an intimate technology composed of transnational circuits of queer desire. The sub-chapter concludes with critical reflections about the globally circulating idea of the universal queer family.

\subsection{1 "I was totally shocked": Siti Mohd Amin}

Siti Mohd Amin moved from Malaysia to Switzerland at the age of twenty-two, more than a decade before our meeting. "I just only come here to work," she states at the very beginning of the interview, having desired work experience as a cook and to learn the ropes of Swiss gastronomy. As a cook specialized in Asian cuisine, she was able to obtain a temporary residence permit for specialized cooks with relative ease. Once in Switzerland, she quickly immersed herself in her job in an Asian restaurant in Bern, where she swiftly advanced to the position of chef de cuisine, leading an international, largely Asian - and interestingly predominantly gay - crew of cooks. Despite her lack of proficiency in the German language and her limited knowledge of English, she acts as the link between cooks and management and fulfills a range of planning and administrative tasks. The immense work load that the position as chef entails have left her hovering on the edge of burnout for several years. Now, at the time of the interview, she has just accepted yet another position as chef, one that she had turned down twice before in order to prevent the impending burnout. Throughout the interview she keeps repeating how urgently she needs to "relax."

Despite the hard work, Siti Mohd Amin stresses how much professional experience she has been able to gather in Switzerland and the extent to which this has extended far 
beyond learning the nuts and bolts of Swiss gastronomy: "The most important I learn here is to stand on my own [feet], you know, I cannot depend on the other person," she states. According to her, gathering experience also encompasses learning the "Swiss mentality" as a whole, and "understanding their culture." However, while Siti Mohd Amin was able to integrate into Swiss working life very quickly (to the point of becoming consumed by it), her attempts to immerse herself in Swiss society more broadly have resulted in partial and ambivalent success only. In part, this has been because of her successful career, the intensity and working hours of which generally leave little space for a fulfilling social life.

For Siti Mohd Amin, it has always been clear that she loved women and only women. She had already entertained relationships with women in Malaysia, and at a point late in the interview she explains that it had in fact mainly been an exceedingly painful separation from a girlfriend ${ }^{7}$ that had driven her abroad:

When break I feel very sad, I stop working [...] for a few weeks. [...] Then I tried to get one new girlfriend, I still not happy. [...] I need to go out from this place to relaxing my mind. [...] That's why I come to Switzerland, this is the main reason why I come to Swiss. So my heart is already broken when I come to Swiss, and I decide to myself to just come straight to job only, don't think about the girl.

- Siti Mohd Amin

Siti Mohd Amin identifies as a pengkid, which, as she explains, originates from gay punk kid and is a self-designation for queer Malaysian women who are aggressive (as opposed to feminine) and entertain relationships with feminine women. Yuenmei Wong describes pengkid as a sexual identity that emerged from the pop culture among working class youth in major Malaysian cities in the 1970s. More recently, "while the Muslim-Malay sexual minorities are increasingly subjected to the threats of moral policing in Malaysia, Pengkid has become a new identity marker for the marginalized sexual subject framed by the Islamic discourse of this country." In this context, pengkid designates "a localized synonym for a masculine-looking Malay-Muslim lesbian who is outlawed in Malaysia through Islamic discourses" (Wong 2012:435-436). The pengkids Wong interviewed in urban Malaysia were predominantly working class and worked in the entertainment industry. According to Wong, in recent years pengkids have become increasingly subjected to moral policing following a fatwa against tomboys (another identity organized around female masculinity), which has increased the visibility and hence the pressure on pengkids and other transgender identities and practices in Malaysia. At the same time, "seemingly rebellious upwardly mobile younger Pengkids nowadays are more empowered to affirm their sexuality and to reclaim the term 'Pengkid,' as lesbians did with 'dykes' in the west, although they are aware that the current political climate in Malaysia is not in favor of their sexual practices" (ibid:443). Siti Mohd Amin contrasts pengkids with tomboys, whom she defines as equally masculine in appearance but not (yet) engaged in a same-sex relationship, and to lezzies, feminine women seeking 'aggressive' female partners. Both in Malaysia and in Switzerland, many people perceive Siti Mohd 
Amin as male at first sight, something she has gotten used to. She and two of her sisters have always been very boyish, Siti Mohd Amin says - her mother used to remark dryly that she had "a lot of boys in the house." While same-sex intimacy was never talked about explicitly in the family, female visitors were silently accepted.

There were a number of misunderstandings in the interview that revealed a great deal not only about Siti Mohd Amin's understanding of her sexuality, but my own contrasting expectations as well. For instance, when I asked Siti Mohd Amin whether she had had any negative experiences as a same-sex oriented woman in Malaysia, she did not answer on a political but on a personal level, recollecting hurtful break-ups. This and other instances indicated that Siti Mohd Amin does not primarily understand her sexual identity in terms of a discriminated positionality. As will be discussed below, it is rather that this marginalized positionality is becoming impressed on her now as younger queer women in Malaysia start to show their queerness more openly in public. In contrast to the narratives discussed in the previous sub-chapter, for Siti Mohd Amin, being masculine and loving women have instead always been obvious and natural. Her narrative reflects no point of realization, no phase of internal conflicts, no questions about communicating her sexuality to anyone or discussing it with anyone, no shame. Questions addressing her coming to awareness of her sexual dissidence seem odd to her. When asked how it was for her when she first realized that she had fallen in love with a woman, she answers: "Happy too much, you know, the smell, the touch, even as you're working, still the memories there." As such, Siti Mohd Amin's story undermines Western homonational imaginations of Muslim societies as intrinsically and pervasively homophobic.

Having said that, when asked whether she or other women in the queer Malaysian community displayed their sexual orientation in public, Siti Mohd Amin assumes a critical stance vis-à-vis a "new generation" of queer women in Malaysia who exhibit their homosexuality more openly. She does not criticize the women themselves but explains that their increasingly demonstrative behavior has provoked increasing repression. "Now you cannot even sit with our own group [...] we are more scared now," she says, "four or five people is okay, but if you more, then they think something." She says that while it is not a state offense to display intimacy in public, it is against "the Muslim rule," which is sanctioned by civil Muslim surveillance groups in collaboration with the police. She observes an increasing number of warnings by queer community members issued over the queer Malaysian chat she frequents. From this, it emerges that the silence and discretion Siti Mohd Amin herself has been practicing is giving way to an increasingly visible queer community as more and more young and urban Malaysian women follow the 'in-your-face' model of living out their queerness. As her statement "we are more scared now" indicates, Siti Mohd Amin continues to conceive of herself as a member of this community, which corresponds with how she is perceived by her Asian acquaintances in Switzerland. As the person who connected us said about Siti Mohd Amin: "I see that she got connection to all the lesbians in Malaysia. She's really like Malaysian, Malaysian. The way she thinks is still Malaysian."

When Siti Mohd Amin left her country, none of these issues were on her mind. However, once in Switzerland her hitherto unchallenged and unproblematic sexual orientation and gender positionality was called into question as several men tried to cajole 
her into having sex with them. It remained unclear whether these were Asian, European or other men. In the case of European men, these advances must be read in the light of postcolonial sexual asymmetries and Western phantasies of the Asian woman as discussed above (see Chapter 3.4.2 and Haritaworn 2003). In either case (that is, whether these advances were made by Asian, European, or other men), it is paradoxically in the context of the European multicultural society that Siti Mohd Amin perceives as particularly "open" that her sexual orientation and her ambiguous gender identity first become seriously challenged. But she was adamant: "If I don't have feeling, how can I make sex with a man?"

Instead, curious to explore the local lesbian community, she soon visited a lesbian club, "just to see how the lesbian is, you know. Their club. I never been here actually before. Even in Malaysia we don't have a lesbian club, and I go see how they enjoy their life, no?" she explained. ${ }^{8}$ But her first visit there took an unexpected turn:

So [that] was shock, total I'm shocked here for first time I going to the lesbian club, you know? It's like different- formation, totally different. [...] The feminine [...] was with feminine. Do you understand what I mean? Asian, a [aggressive] person like me, my couple is feminine, but here it's different, they are totally the same- feminine/feminine, and the aggressive one is with aggressive.

- Siti Mohd Amin

Siti Mohd Amin was disoriented by the gender pairings bringing together two feminine or two masculine women. Uncertain which women to approach, she concluded: "I do say forget it, you just come here and enjoy, you know. Listen to Musik [German pronunciation], enjoy ourselves." This dismissal has proved terminal: In the eleven years since she has come to Switzerland, Siti Mohd Amin has never had a relationship with a Swiss woman or generally with women she met in Switzerland, but has instead sought relationships with Malaysian women in Malaysia and elsewhere, which she has established during her annual visits to Malaysia and over queer Malaysian internet and chat sites.

Her perplexity about her encounters in Swiss lesbian bars is thereby only one factor in her decision not to invest too much energy in finding access to the Swiss lesbian community, the other being her preference for Asian women and "culture":

I mean I still like my culture, you know? [...] I like the Asians more cause it's the sweet face, no? [...] Because they know how to respect also, this is what I like more to Asian. And I didn't try anything with the Swiss people, [...] I want to try also with the Swiss people but I don't get it, you know (laughs)?

- Siti Mohd Amin

8 She adds that there had been (illegal) gay clubs in Malaysia, and that queer women would meet up in these clubs as well. However, especially for political dissidents or people that have been apprehended by the police before, it was not advisable to visit these clubs. Apprehended gay people were often sent to mental institutions where they were subjected to treatment for homosexuality. As Siti Mohd Amin observed, feminine women ran less of a risk of being caught because their queerness was not visible. 
At the same time, Siti Mohd Amin's transnational relations are equally fraught with confusion. In her absence, the queer Malaysian lesbian subculture is developing and changing, and is starting to fail to provide Siti Mohd Amin with the comfort of familiarity and the sense of belonging she seeks: "Actually I quite shocked also because whenever I go back [to Malaysia or Malaysian chat sites] it was new names coming, you know," like lezzie, PLU (People Like Us). As she tells me this, she tears her hair in frustration.

In other words, Siti Mohd Amin's membership in both the Malaysian and the Swiss queer community remains precarious, with neither identity nor community offering her the social home she seeks. Her love life, too, is fraught with painful separations. Dissatisfied with long-distance situations, her Malaysian girlfriends never stay in the relationship long, either cheating on Siti Mohd Amin, leaving her for a man, or returning to their husbands. Siti Mohd Amin expresses understanding: "They cannot wait for me for the long year, so sure they are bored." At the same time, she feels grossly misjudged by her reputation as a "player" in the Malaysian community. She considers herself to be monogamous and faithful, always ending one relationship properly before beginning a new one. Her desire - and this is one of her uppermost goals in life - is to find a long-term partner with whom to share everyday life in Switzerland and later in Malaysia.

The obstacles to achieving this goal reach beyond the difficulties of a long-distance relationship. According to Siti Mohd Amin, the longevity of female same-sex relationships in Malaysia is highly gendered. In her experience, 80 percent of the women engaging in same-sex relationships in Malaysia, the "feminine" ones, will "change their life" after one or two years, in order to "follow the culture," that is, to marry a man and establish a family. "This is somehow still in their mind, you know?" She says it is what is normal for Asian women and is implemented "automatically." On the other hand, aggressive women like herself, "we already thinking far away, no? [...] So we [do not think] in a short year, not in five years, at least ten or twenty years, that's different. [...] That's why I say to you in ten years I change[d] four girlfriend because they change. Not me change." One could thus say that Siti Mohd Amin frames her girlfriends' samesex desires as something these women do for a period of time, while for her it is something that is not changeable, that she is, and accordingly as something around which she organizes her future.

Siti Mohd Amin's discomfort with the Swiss lesbian community, her dissociation from the Malaysian expat community (which she considers heterocentrist and conservative and therefore only fit for a bout of small-talk in her mother tongue, see Chapter 7), her estrangement from the queer Malaysian community, and her working hours lead to a life marked by social isolation, interrupted only by video conferencing sessions with faraway girlfriends at odd hours, the occasional outing to the city with a friend, or a rare game of badminton. She suffers from the fact that she does not know any other queer Malaysian in Switzerland with whom she could "sharing problem together."

Her social isolation in Switzerland plays a key role in Siti Mohd Amin's deliberations about going back to Malaysia. When she came to Switzerland, she had sought to mend her broken heart, but she had also come here to learn about gastronomy and earn enough money to go back to Malaysia to open her own restaurant. This has remained 
Siti Mohd Amin's professional plan throughout her eleven years in Switzerland, in contrast to many other interviewees who had also not come to stay but have since changed their mind. She intends to go back before turning forty because it is hard to get a job in Malaysia after that. Two main considerations propel her plans to return. First and foremost, Siti Mohd Amin strives to create a situation that enables her to forge the desired committed long-term relationship:

I like to go home. I like to stay in Malaysia actually - because I was missing something here, you know. There [is] no life, it [is] only working and working, working place and home, you know? [...] I do not have a girlfriend here, just only I go home [to Malaysia] then I'm with my girlfriend, so once a year, two times a year, it was nothing actually. Actually I wish to have my girlfriend also together so we can sharing the life here, but no? I cannot, [she is] actually also working in Malaysia.

- Siti Mohd Amin

Her immense workload renders it impossible for Siti Mohd Amin to forge new relationships in Switzerland or maintain her long-distance relationships in a meaningful way. Her second reason for going back is therefore to establish an everyday life that is more "relaxing":

I open the restaurant [in Malaysia] but I just thinking to open a small thing, that is... I just only working one or two person enough, just to survive, you know? Cause for money also it's not important, you know. Don't mean anything. I just can alive the daily, the monthly, this is more than enough for me. Because l'm already tired, you know. Work in a hard place, the two place that I work [in Bern] is so bumping restaurants, you know. Soon I need to go relaxing also, I mean, relaxed place, and some money is enough.

- Siti Mohd Amin

In light of the material discussed so far, Siti Mohd Amin's account depicts her ongoing quest for a place in the world. Instead of a sense of homecoming, she conveys a sense of social isolation and frustration. The cause for this she locates, on the one hand, in her failure to understand Swiss lesbians' ways of pairing up and hence to find intimacy within the Swiss lesbian community, and generally her lack of a companion in her everyday life in Switzerland. The differences between Asian and European sexual minority (sub)cultural practices emerge as insurmountable, as do the language barriers presented by her lack of German and many Swiss lesbians' relative lack of English. On the other hand, Siti Mohd Amin understands her frustration and sense of isolation as results of her unsuccessful efforts to salvage her membership in the queer Malaysian community, from which she is largely absent. In other words, Siti Mohd Amin both refuses and is denied the positionality of the 'good lesbian.' This bars her from access to the Swiss lesbian community and to Swiss (sexual) citizenship.

At the end of the interview, when asked if there was anything else she wanted to say, Siti Mohd Amin swiftly returns to the issue of gender positionalities:

In the beginning I have girlfriend is all soft girlfriend, you know. Where it's soft character, sweet... and then, after a few years, I change a bit, I say it's better don't take a 
partner is same character. [...] I'm not romantic, but [...] maybe I be a bit soft for my girlfriend, you know? So then I think it's better not to take same character. Better take some aggressive, I mean, aggressive from character [does] not mean... it's still feminine but aggressive, yeah? So I change a bit. [...] This is also good thing to learn, you know? [...] Some[times] your girlfriend [is] also right, you can sharing your idea. Before, my first girlfriend, whatever I said she just say yes yes yes yes. Also no good, also no good. [...] And before, just when beginning, I got always fresh girl, yeah? They don't know anything (laughs). So it's hard to teach a person just know about relationship, you know. How you have to teach how to kissing everything all, you know. How to make love. Then after a few girls then I change to the person who already have experience. [...] And I'm totally shocked, because her knowledge is more than me. [...] That's my first sex where l'm total surrender you know, because she is more experience.

- Siti Mohd Amin

In this passage, Siti Mohd Amin's most intimate space - her body, her character, her sexuality, her understanding of relationships - has begun to shift. The comment critically undermines the "aggressive" gender identification Siti Mohd Amin has been establishing so extensively throughout the interview. It confirms her preference for what she terms "Asian" women (whom she defines by their specific complexion and their "Asian" feminine comportment, such as "showing respect") but adds the realization that the gender roles she has been enacting and sought in her relationships have become incongruent with what she seeks. She detects a "feminine" side to herself that she did not know or acknowledge before, and has developed a preference for stronger and more assertive partners rather than subservient and inexperienced ones. However, the heteronormative ideal stays intact despite this shift: Because she has become more feminine, Siti Mohd Amin now seeks out more masculine partners - which continues to foreclose the possibility of two distinctly feminine or masculine women engaging with each other. This development does not suspend Siti Mohd Amin's estrangement from the Swiss lesbian community, where she feels put off by equally gendered couples.

This is not to say that Siti Mohd Amin's attitude is generally closed towards what she terms "Swiss culture." Quite to the contrary:

I just do it [the migration] for this culture shock, you know. And I go to Swiss, okay, I notice how the mentality here. And I go back Malaysia I used to do also with their culture and mentality, you know, so I can go to the different culture also. [...] Some is good things you take. Or it's not good, you don't save, but you just only take it in, remember this is something you better not follow, but take for your experience these things.

- Siti Mohd Amin

Asian and European "culture" appear as bounded and dichotomous here - "Swiss people mentality is like this, Malaysian like that," as Siti Mohd Amin states elsewhere. At the same time, as a migrant she explicitly situates herself in a hybrid position that enables her to overcome cultural boundaries and to make choices. Siti Mohd Amin hence sees her position as in between, where the "cutting edge of translation and negotiation" occurs (Bhabha 1996). She sees herself as composing her individualized and optimized 
mix of what she perceives to be Malaysianness and Swissness respectively. This per se may be read as an act of neoliberal self-realization and hence adaptation to Western ideals; but Siti Mohd Amin transgresses the boundaries of 'good' European citizenship, especially also through her refusal to discard her Malaysianness in order to become a 'good lesbian' (and hence her refusal of lesbian norms in Switzerland) and her decision to choose Malaysian women as partners instead. In Siti Mohd Amin's story, the drivers of her personal development are moreover situated outside Switzerland, which disrupts the dichotomy of a progressive West versus a passive, backward Orient: It is especially Siti Mohd Amin's new, sexually experienced Malaysian partner who induces the shift in her gender identification. This is, for instance, in contrast to Augusta Wakari's narrative, who locates the driving force behind the positive complication of her gender identity in her Belgian partner.

In sum, Siti Mohd Amin's migration biography demonstrates that social inclusion in general and access to the Swiss lesbian community in particular is neither obvious nor unproblematic for women who already assumed a queer sexual identity before migration, and who were members of a sexual minority community in their countries of origin. Her eventual failure to connect to the Swiss lesbian community is at once a process of being excluded and a process of self-exclusion: Siti Mohd Amin's efforts to connect to Swiss lesbians remain fruitless but are also depicted as half-hearted, which is reflected in her decision to invest her (limited) energy in long-distance relationships to fellow Malaysian women. Her narrative grounds this choice in the perceived inaccessibility of Swiss lesbians and the cultural gap between sexual subcultures, which eventually overrides her efforts to integrate Swiss and Malaysian 'culture.'

\subsubsection{Transnational Intimacy in Cyberspace}

In addition to her workplace, cyberspace emerges as the most important space in Siti Mohd Amin's everyday life. Since virtual space plays a significant role in many other interviewees' biographies as well, this sub-chapter elaborates on this aspect of Siti Mohd Amin's account, but then moves on to include material from other case stories to saturate the analysis of what cyberspace means to the interviewed queer migrant women.

From the narratives, the internet also emerges as a queer space, serving as a container for a vast collection of information about many aspects of queer life, and as a space that enables social relations with other queer people near and far. Interviewees appreciate and take advantage of the fact that information that could formerly be obtained only by exposing oneself personally in an office, library, bookstore, cinema, or club is now accessible from the private space of the home. Anonymously if desired, and usually in multiple languages, cyberspace provides access to queer films, literature, and music, to lists with homo-friendly psychotherapists or immigration lawyers, information on lesbian mothering in Switzerland, and so on. On the other hand, participants use the internet as a technology to establish and maintain relationships, queer and otherwise: video conferencing with relatives and friends back home, discussing issues of gay and lesbian parenthood on online forums, connecting to queer women back home via social media, looking for new friends or partners on chat and dating platforms, or 
establishing and sustaining friendships and partnerships via video conferencing, social media platforms, chats, or e-mail. This sub-chapter focuses on these latter aspects of cyberspace: its role in the establishment and maintenance of social relations in general and romantic partnerships in particular.

It is hard to discern whether Siti Mohd Amin started dating Malaysian women on the internet because she found herself unable to gain access to the Swiss lesbian community, or because she did not devote a great deal of effort towards connecting to Swiss lesbians because she prefers Malaysian women as girlfriends. Over a social media site geared towards queer Malaysian women, Siti Mohd Amin remains connected to the queer Malaysian community by keeping up to date with political and subcultural developments in Malaysia, forging transnational friendships, and looking for a new girlfriend from time to time.

At the time of the interview, Siti Mohd Amin has two girlfriends. She has lost touch with the first to an extent, a Malaysian living in Malaysia, who has had a new boyfriend for a while and has neglected Siti Mohd Amin since:

I'm waiting here so for her message, for call, even for her mail. [...] But I was waiting and thinking myself, all the time l'm thinking about her, but she don't care. [...] And then, [I] just go back to Malaysia without her knowledge, and I find out [about the boyfriend], it's clear for me, I say okay, it's up to you, what you want to do, but I, for me, when I have another girl, you don't say it's my fault, it's also your fault, you know. So for one year I was suffering alone, I was waiting for you, your missed call, your voice, at least for your voice so we can feel good, you know? [...] Yeah, sometimes fact sad thing, in your life.

- Siti Mohd Amin

This is a pattern Siti Mohd Amin is all too familiar with, having been left by "heterosexual" long-distance girlfriends in Malaysia three times before. "Ten years. No one can wait for you," she states laconically. After this specific visit to Malaysia, she became active in the transnational Malaysian queer online community again and soon found a new girlfriend, a Malaysian living in the Middle East. Since Siti Mohd Amin has never broken up with her original girlfriend, she understands herself to be in two simultaneous relationships, but stresses that her two girlfriends are aware of each other and have consented to the situation.

While due to the time difference she usually only chats with her girlfriends in Malaysia on weekends, the location of her new girlfriend allows for more daily contact: "We are different two hours so we quite often chat every day, you know? [...] So most I come home twelve thirty at night then I will chat each other, so we see each other quite often," she explains. The slight irritation the formulation "seeing each other" evokes is only partly resolved when thinking of these exchanges in the context of video conferencing. As Siti Mohd Amin describes the couple's online habits:

From webcam. So I can see what she's doing, sometimes she went to sleep. She likes to sleep more. I say 'Okay, you go to sleep,' but webcam is still open (laughs). I can see her. How are you, sleepy. And I say 'Huh, you are too aggressive when you sleep, right?' (laughs) [...] And somehow we just open up our webcam until in the morning, and she can see also how l'm sleep, she says 'It's so cute, you sleep.' (Pause) Yeah, because from 
the sleep you can see how the person is, no? Exactly. (Pause) One time I tried to say uh'It [does] not mean you can make love only in the bed. You can make love also in the webcam' and then I tried to say 'Ah, come baby let's go-' (laughs) and she was being shy about that.

- Siti Mohd Amin

Although the webcam works as a transnational technology of intimacy, it cannot replace "seeing each other" physically, but Siti Mohd Amin sees both of her girlfriends only once or twice a year, a situation far removed from her wish "to have my girlfriend also together so we can sharing the life here." She has tried to convince her new girlfriend to find a job in Switzerland, but they did not succeed in finding a position due to language issues, so with the exception of a short period of time when one of Siti Mohd Amin's girlfriends (and her baby) lived with her in Switzerland, Siti Mohd Amin has exclusively entertained long-distance relationships, which moved her computer and cellphone to the center of her everyday routines.

The same focus on cyberspace also emerges from Maria Borkovic's account, who took a picture of her living room for this research, which is organized around the desk accommodating her computer. "This [is] my world," she remarks upon the picture, "I mean I go on Skype and talk. Yeah, that's my only connection with like social- really (laughs)." After failing to find any friends in Switzerland despite her persistent efforts to connect to other lesbians (she had already identified as a lesbian before she came to Switzerland from Hungary), cyberspace has become her only door to the social world:

This is really bad experience for me for these beginning of months I really was so depressed. I mean I have Skype you know, my computer, and I talk everyday with my girlfriend, with my friends, families and I think if I wouldn't have that I would be just really like depressed.

-Maria Borkovic

Maria Borkovic shares this experience with other interviewees, like Ayesha Umar, who sees writing e-mails and teleconferencing as "Ersatz" - replacement - for physical contact with people in her everyday life. In addition to cultivating relationships with loved ones back home and mitigating social isolation while in Switzerland, many interviewees also use the internet in their attempts to connect to people within Switzerland. Maria Borkovic is among them. In her efforts to find a friend she has been stood up by women she had made an appointment with. However, the reason she eventually abandoned these efforts is not her frustration at her lack of success but her long-distance partner's jealousy:

I actually I did have problems with my girlfriend because I was on these sites (laughs), you know [...] she is really jealous, really, and she found me on this [Swiss Lesbian chat and dating site], it was really a big problem, and I was explaining her just because I really really want to find a friend like not a girlfriend but just, you know, a friend. [...] I usually use this always the same nickname and I had my picture there (laughs) so she find it and really had problem with that and I said 'Oh come on, I'll stop it you know, anyway I wanna stop that because [...] you know [I was at] this gay party it was really good, but just nobody cares about me you know they just don't want to talk with me 
so you don't have to, you know, panic, there is nothing to panic about, there cannot be anyway anyone so.' And I just, yeah, stopped, I didn't bother anymore the cyber friendship (laughs).

—Maria Borkovic

Maria Borkovic's failure to connect to lesbians in Switzerland both on- and offline demonstrate the shortcomings of a view of cyberspace as a boundless and democratic space for unlimited connectivity and self-invention. Social boundaries presented by cultural differences, language barriers, and other obstacles persist online, as do constraints like the jealousy of a partner.

There were moments in which the fragility of online social connections became unmasked and was replaced by a deep sense of disconnection and loneliness. This was the case for Siti Mohd Amin when she realized that she was no longer able to comprehend developments in her queer Malaysian online community, or for Charlotta Sembiring, who realized when her cellphone was stolen how heavily her sense of security and connectedness depended on having access to cyberspace. This theft happened on the very day her girlfriend, with whom she had just broken up, left her to go back to Indonesia. Charlotta Sembiring's account of this moment is of great urgency, and she describes it as the most incisive moment in her migration biography. Migrating to Switzerland had been a hard moment in Charlotta Sembiring's life. She had left Indonesia and her husband five years before the research interview on a Dutch scholarship for a $\mathrm{PhD}$ program in Holland. As soon as she had established herself in Holland - where she could fall back on an extensive Indonesian diaspora, and (after acknowledging her homosexuality) a vibrant queer community - her professor was appointed to a Swiss university, and Charlotta Sembiring had to follow her. She describes what this meant for her in terms of her social network:

Well okay when I was in Indonesia what I call close friends like, one hundred (pause). Sounds very strange but [...] I mean many people do the same, because there is so many space for people. For relationship, for friendship, for being with a lot of people. And then in Holland like, okay reducing, eh? from one hundred to like, okay then twenty. I started to adapt myself to get involved with less people, okay. And then I came to Bern it's like: one.

-Charlotta Sembiring

For Charlotta Sembiring the city of Bern felt "completely dry," and two successive breakups that coincided with her move to Switzerland accentuated her sense of loneliness:

Well anyway then I broke up with the second one and then I felt completely disconnected and dislocated. With the city, with the people, with everything, it was like I was really feeling like I needed to live anywhere. But. Not. Here. [...] Well, okay, I cannot say that it's because of Switzerland on first note. It has been also started when I was in Holland. I'd been leaving in my country for five years at the time, right? And I missed a lot of things. Actually I lost a lot of friends as well [...]. Now I need this more and more. It was kind of urgent need to be accepted to be part, to be known, to know more people, yeah, it's just like l'm still feeling isolated in the first year. 
The decisive moment that crystallizes her losses and her sense of isolation immediately followed the moment her second girlfriend left Switzerland from Zürich airport to return to Indonesia. Charlotta Sembiring describes this moment as follows:

And then the second girl just left for Indonesia and as she left I was on Crosse Schanze [park in Bern] because I know I didn't dare to come home. I know nobody is at home. And I went to Crosse Schanze and like okay, I bought a book in Sudoku [...], it was Sunday I was just sitting and doing Sudoku, and then I got SMS [text message] from someone and I replied so I placed my hand phone somewhere on the top of my pack, and then after a couple of minutes I wanted to move because it's too hot. And I saw that my mobile was not there. Then okay, should be there I mean I read just an SMS and I never put it inside, just on top, so I just look around and then I realized that it was stolen. (Pause) And that's really the second time I felt completely disconnected and dislocated. It was like in the translation movie ${ }^{9}$ (laughs). [...] It's like I was- so where should I go? Yeah? I didn't know where to call, I didn't know whom to call, I have no mobile, I don't remember the numbers. The last place I want to go is home. I mean home, this place yeah? [indicates her one-room apartment, where the interview is taking place] But this is the only place I could go to because I don't want to stay in Crosse Schanze anymore. I was just walking from the park to the bus stop it was just likeages (laughs) it was only one two minutes, it was like ages (breathes in) just like everything slow motion but it's not. I was completely aware of everything so I was taking care of the movement, so not cross the red light or hitting people or yeah. So, I was like reallyreallyreally, I was- my mind my spirit, only my body was there. My mind I sense that they are inside but the spirit was gone, the emotion, I didn't feel anything but I just wanted to disappear. Absolute disappear, didn't know where, but not here. I was really hurting everything. And I feel the breakdown. (Pause)

Then I'm talking to Julia who is a professor, [...] who was in my group [at university]. And she is lesbian (laughs). And she is Jewish (laughs). So you find like we have something in common, minority eh? (laughs) [...] And it was miles like bringing me up you know, like because I wanted to stop my PhD, I wanted to leave this city, this country, and the only place I could think of well-where else except Indonesia, even though I really don't want to go there but that's my home country. [...] Like because my passport's there. Whether I like it or not or they like me a lot but I have a right for it and in other place I don't, so at least a security feeling so to say, security for that you can go back there [...].

—Charlotta Sembiring

It is in the moment in which Charlotta Sembiring's access to the internet is barred that she "feels the breakdown," and realizes the fragility of cyber connections and the significance of the physical absence of her friends, family, and lost partner, while at the same time experiencing, in a very physical way, her disconnection from the place in which she is physically located. Eventually the physical presence of a person she can relate to on the basis of shared experiences helped her to overcome her crisis. The delicate sense of security she had been able to construct via cyberspace since emigrating from Indonesia 
with partners, friends, and family was shattered physically and symbolically by the theft of her cellphone. In this crisis, it is her Indonesian citizenship that provides her with the last shred of a sense of security.

In these accounts, cyberspace emerges as a space that is simultaneously present and absent, both 'at home' and 'away' (Kuntsman 2004:6 and 2009). It is an intimate space because it is usually accessed from the private space of the home or from a personal device like a cellphone, through which a sense of connection to friends and family can be constructed and maintained. At the same time, cyberspace epitomizes travel, exploration, and, in the case of cybersex, physical transcendence. It is a site in which both connection and disconnection occur. Many interviewees use the internet on a regular basis to keep in touch with their family, partners, and friends living 'back home' or abroad (Gajjala 1996). ${ }^{10}$ At the same time, cyberspace not only bridges but paradoxically simultaneously highlights physical absence, a contradiction that materializes in moments of crisis in which the virtuality of cyber connections is exposed, triggering a deep and very physical sense of isolation and loneliness.

For queer migrant women, cyberspace also enables the creation of imagined communities without physical equivalent: In its function as a communication platform and community building technology for socially marginalized and/or physically dispersed groups, for queer migrant women like Siti Mohd Amin, cyberspace can become the only everyday space where they can be open about their sexuality and where they may at the same time share their language, national identity, and cultural background with other online community members, enabling the interlocutors to tend to their 'homing desires' in both a sexual and cultural sense (Brah 1996).

In her analysis of a web platform for Russian LGBT people in Israel, Adi Kuntsman says (in relation to her own biography) that as a queer Russian in Israel "in the mid-1990s, lesbian identity was constituted through detaching from Russianness; the language, the appearance, and the identification with other Russian-speaking immigrants. In a way, the [web] site became my way back to Russian identity, or at least some parts of it" (Kuntsman 2004:5). The important difference between Kuntsman's and Siti Mohd Amin's narratives is that Siti Mohd Amin has never discarded her Malaysianness; and that Kuntsman's own physical location - Israel - corresponds to the physical location of many members of her online community, allowing her to maintain a dense mesh of on- and offline contacts that may provide her with a sense of full membership in this community. Siti Mohd Amin, on the other hand, is physically isolated from the members of her online group. Despite her active membership in an online community, she cannot fully comprehend the changes the community is undergoing offline and feels disoriented in the landscape of new homosexual identities springing up in on- and offline life in Malaysia and Malaysian diasporas. Instead of achieving the desired sense of home and belonging, Siti Mohd Amin consequently suffers from a growing sense of anxiety, insecurity, and exclusion.

10 Note that internet usage was not equally distributed among interviewees and was especially contingent on age and class. Suki Schäuble, for instance, who is older than most other interviewees, prefers the telephone to keep in contact with her family and partner in Japan. She says she hates the internet and considers her rejection of it a "Cenerationenfrage" - a question of generation. 
Nermina Petar's 'Swiss' online strategy, finally, calls attention to another peculiarity of cyberspace that ties the internet to the previously discussed processes of becoming a lesbian in Switzerland. On Swiss lesbian chat sites, Nermina Petar has come to mask her migrant identity by means of a nickname that does not reveal her migrant background:

Und vor allem irgendwie Nermina kommt immer wieder die Frage ja, von wo bist du, bist ja keine Schweizerin oder? Und irgendwann ja, aufden Nerv gegangen, [...] 'Nermina die Ausländerin' in dem Sinne. Und dann habe ich einfach einen [online] Namen gewählt der einfach [...] normal ist. Nicht irgendwie auffällt in dem Sinne. Und seitdem bin ich Nora, im [Name einer lesbischen Chatseite] bin ich auch Nora und in der Szene bin ich Nora und sie [Partnerin] nennt mich Nora, irgendwie gehört der Name dazu, oder? Ich kann ihn gar nicht mehrändern (lacht).

And above all, somehow Nermina always gets the question where are you from, you aren't Swiss, are you? And at some point this annoyed me [...] 'Nermina the foreigner,' in this sense. And then I just chose a [online] name that is just [...] normal. That does not catch your eye in this sense. And ever since I have been Nora, on [name of lesbian chat site] I'm also Nora, and in lesbian circles I'm Nora and she [her partner] calls me Nora, somehow the name belongs to it, you know? I can't even change it anymore (laughs).

-Nermina Petar

In her need to establish an effective protective shield against the exclusion she has been experiencing online, Nermina Petar disguises her cultural difference. The possibilities of the internet hence allow queer migrant women to step into a social positionality that is often not possible to assume in physical spaces. At the same time, Nermina Petar's move perpetuates the imagination of Swiss lesbian spaces as homogenously 'Swiss.' By shedding what marks her as an Ausländerin online - her name -, Nermina Petar's strategy unwittingly re-enacts the invisibilization of migrant bodies in the Swiss lesbian community and hence whitewashes its spaces. In such ways, effectuated by racism and xenophobia aimed at queer migrant women, lesbian spaces perpetuate themselves as white. In Nermina Petar's case, this mechanism even extends to the real world as she starts using her online name in physical social interactions as well.

To sum up: For interviewees in this study, cyberspace is an ambivalent space of connection and disconnection, presence and absence, in- and exclusion. On the one hand, some online communities open up intersectional spaces that offer queer migrant women a space to accommodate multiple aspects of their Selves, where they can especially also share common experiences of social exclusion. As such, these online communities represent spaces which hardly ever have a flesh-and-blood equivalent in their everyday lives; there is no space where Siti Mohd Amin can be at once queer and Malaysian except for the queer Malaysian online community. Since it is exactly due to their intersectional subject positions that queer migrant women in Switzerland are at a higher risk of being exposed to social isolation and exclusion, the role of cyberspace in forging social connections is difficult to overestimate.

On the other hand, mechanisms of exclusion in the 'material' world also extend to cyberspace; for lack of physical presence, Siti Mohd Amin has failed to maintain full membership in the queer Malaysian online community, so that it has eventually re- 
mained impossible for her to experience sexual, ethnic, and diasporic connectivity simultaneously. This has resulted in a lack of spaces, on- or offline, where she can "sharing problem together." Participants in this study in general mostly have to 'make do' with partial identification: On the one hand, in Swiss lesbian cyberspace, they experience exclusion as non-German/French speakers, which complicates or even precludes their participation and membership in these spaces, not to speak of sharing their experiences as (queer) Ausländerinnen in Switzerland. On the other hand, on websites and social media platforms and chats based in queer communities in their home countries, they often cannot share their specific immigration experiences in Switzerland and like Siti Mohd Amin are barred from full access to membership due to their missing physical presence. Lastly, in cyberspaces addressing expat compatriots in Switzerland, interviewees often feel they cannot be open about their sexuality (see Chapter 7).

Online practices and strategies are closely linked to sexual self-conceptualization. Efforts to integrate into the Swiss lesbian community often include participation in the Swiss lesbian online community, while dissociation from this community is often coupled with an absence from these virtual spaces. Nevertheless, the relationship between on- and offline identification remains complex and contradictory. Efra Mahmoud, for instance, who does not identify as a lesbian, still resorts to this identity strategically when searching online for a lawyer specialized in immigration by homosexuals, as will be seen below.

Other questions remain as well, such as who is allowed a voice in cyberspace, who is able to create a sense of belonging in which online communities, and who is able to transform connections established online into physical connections and hence social and other types of capital. The accounts discussed here certainly call into question the perception of cyberspace as a site of unlimited participation and self-invention; but at the same time, they demonstrate that cyberspace is never a mere reflection of offline spaces or identities but can also extend or limit them. As Kuntsman writes:

'Cyborg-Diaspora' [...] is a space for creating migrant community through technology that can disrupt dominant discourses of nation, ethnicity and culture. It could also be a space where immigrants can resist the hegemony of language of their host society. For example, the website's name, 'The Pan-Israeli Portal of Russian speaking GLBTs,' challenges the Zionist idea of Israeli identity as embedded in Hebrew language, and proposes instead a new kind of identity: a Russian-speaking Israeli. It thus creates a new home - in language and in cyberspace. (Kuntsman 2004:6)

By contrast, even though Siti Mohd Amin's Malaysian online community is intrinsically transnational, she cannot integrate her specific experience as a queer Malaysian in Switzerland. This creates a sense of isolation and excludes Siti Mohd Amin from the ongoing transnational negotiation of Malaysian queerness.

\subsubsection{We Are Family - Not}

When Siti Mohd Amin arrived in Switzerland, she was curious to discover how Swiss lesbians "enjoy their life." She was eager to find out what it feels like to be in a lesbian club, which she had never experienced before due to the lack of women-only clubs in 
Malaysia. Siti Mohd Amin expected something, and this image was magnetic. However, what had been imagined as a homecoming ended in repulsion, exclusion, and disillusionment. Maria Borkovic shares Siti Mohd Amin's experience of disappointment in the Swiss lesbian community, having migrated to Switzerland from Hungary partly explicitly because of the lesbian community she imagined to thrive there. For her, moving to Switzerland was also moving away from what she experienced as increasing homophobia in Hungary to a "more liberal" political climate, and accordingly she expected lesbians to be situated differently in Swiss society than in the Hungarian context. However, as Kath Weston remarks, "homelands can be easier to desire from a distance than once you arrive on their figurative shores” (Weston 1995:275). Maria Borkovic's persistent and committed efforts to connect to Swiss lesbians fail, giving way to frustration and social isolation:

Actually I tried making friendships [with Swiss lesbians] on internet as well. And there was two girls, one was writing me back but because I said I can write a bit German but I would rather prefer she can talk English. Some didn't really respond and some we exchanged couple of letters but it was like- even exchange the mobile numbers so maybe we will meet and then it just like disappeared. [...] So this was actually the point when I was really really frustrated. [...] I was really frustrated that you come here, a foreigner, okay, I accepted that I'm foreigner I cannot really talk to Swiss people. Buy if you go to really like a gay society you also have this discrimination because you are a foreigner. So it's like really unexpected for me, I really thought it was gonna be a chance for me? That you know, gay people don't make difference whether they are from I don't know Peru or China or whatever. It's like more open society for me at least, more liberal and even there you just don't really get this perception of acceptance if you are gay. So it is really hard [...] for me when I kind of had this bad experience so far and this is when I saw your [research] topic and I was really interested, I really wanted to talk about. -Maria Borkovic

Maria Borkovic understands herself as a member of the universal lesbian family, which she believed was going to offer mutual support and acceptance against the backdrop of shared experiences of discrimination. Accordingly, she expected Swiss lesbians to be 'better' people, open and welcoming towards international queer fellows. But what Maria Borkovic saw as a gateway to friendship and connection in Switzerland turned out to be another space of exclusion, only this time based upon her being an Ausländerin.

When Maria Borkovic first read the call for participants for this research on the website of the Lesbenorganisation Schweiz LOS, she became angry. Since the call placed there was written in German, she did not understand the research context in detail and thought it was an effort by Swiss lesbians to establish a queer migrant self-help group:

First I thought that (laughs) your topic is actually about a kind of gathering women club or something like that who are foreigners, and you can come and be friends here, but don't make friendship with Swiss women. [...] So saying that if you come from whatever Eastern Europe or Asia or whatever then you have to be part of one club, isolated, and not like you know, trying to assimilate with other Swiss women, this is how I took it. -Maria Borkovic 
Maria Borkovic was enraged at what she understood to be plans for a queer migrant group schemed by Swiss lesbians, which she interpreted as an effort to ghettoize immigrant lesbians instead of welcoming them into the folds of the Swiss lesbian community. When asked how she would have reacted to a group initiated by queer migrant women themselves, she replies that this would have changed her perspective on the project completely, and that she would appreciate such an effort.

Siti Mohd Amin's and Maria Borkovic's experiences indicate that queer migrant women in Switzerland cannot participate in the imagined community of the universal 'queer family' in the same ways as non-migrant lesbians. Their experiences of exclusion expose the specificity of the lesbian identity and subculture and the effect its implicit whiteness and 'Swissness' has on migrant queers who do not share the sexual biographies and other formative experiences of women who grew up in Switzerland. Queer migrant women's perspective hence counteracts the postulation of unity in a universal 'queer family' that continues to dominate the imaginaries constructed by queer women around the globe - including that of Siti Mohd Amin, Maria Borkovic, and many other participants in this study.

\subsubsection{Conclusion}

Working outwards from Siti Mohd Amin's migration biography, this sub-chapter engaged with the question of how women who had been members of a sexual minority community and/or sexual (sub)culture before emigrating experienced their arrival in Switzerland and in the Swiss lesbian community in particular. Instead of the expected sense of homecoming to a universal 'queer family, experiences of repulsion and exclusion in Swiss lesbian spaces put an end to the harmonious image some of the participants in this study had harbored about Western lesbian communities prior to immigration. Maria Borkovic has not been able to forge meaningful social relationships within the lesbian community despite persistent efforts. By contrast, Siti Mohd Amin has resigned in the face of (sub)cultural differences she perceives as insurmountable; refusing to discard her 'Malaysianness,' she has failed to become a 'good lesbian' and is hence barred from access to the lesbian community in Switzerland.

This disillusionment with and failure to access the Swiss lesbian community leads to frustration and social isolation - which is frequently aggravated by abusive work situations as well as by the absence of alternative spaces to establish social connections. Among the strategies employed by study participants to mitigate the experienced social isolation is an increased focus on cyberspace and transnational relationships and intimacies, which at once counteracts and propels social isolation. At the same time, membership in queer online communities based in the home country remains partial, and transnational long-distance relationships are frequently brittle and conflict-laden; neither can it replace membership in a physical queer diasporic community.

The 'culture shock' Siti Mohd Amin experienced in the Swiss lesbian community is mirrored in Marc Thielen's (2009) study, in which he analyzes the migration biographies of queer male Iranian refugees in Germany. The queer refugees' narratives Thielen discusses create a binary between gay men from the Orient (characterized as soft, ro- 
mantic, and loving), and men in the German gay community (characterized as focusing on casual sex, lacking love, and reducing men to sexual objects). These imaginations and experiences complicate the biographers' access to the gay community in Germany. This result parallels the finding that non-Western sexual identities lived in queer subcultures in the home country prior to migration and (online) membership in transnational sexual minority communities based on these identities can end up snagging queer migrants' access to the gay or lesbian communities in the receiving societies. By refusing to shed their sexual identity and hence by refusing to become assimilated 'good lesbians' (or 'good gays'), they are at the same time excluded and exclude themselves from these spaces. From this, lesbian and gay communities emerge as bounded, closed spaces disciplining - or excluding - migrant sexualities.

\section{3 "It's like a stamp": Rejecting the Lesbian Label}

Some interviewees explicitly rejected the lesbian identity or any other same-sex 'label.' This sub-chapter engages with this last trajectory, first by tracing Efra Mahmoud's migration biography. The second part then juxtaposes Efra Mahmoud's positionality vis-à-vis the figure of the lesbian with those of non-migrant women, demonstrating that ambivalence regarding the lesbian identity does not hinge solely on being an international migrant. The final part addresses a prominent theme in Efra Mahmoud's account: intersections between religious identity and sexuality.

\subsection{1 "It's like someone has a stamp on their forehead": Efra Mahmoud}

Having completed a Master's degree in Egypt, Efra Mahmoud toyed with the idea of continuing her social sciences studies abroad. She thought of going to America, but shied away from the language tests she would have had to take. One day she saw an ad by the Swiss embassy for a scholarship to study in Switzerland and spontaneously applied. One year later, she was told she had been accepted and that she could leave for Switzerland within the month. Efra Mahmoud had almost forgotten she had applied, but within four weeks quit her job, learned the Roman alphabet and a few words of German, and left her family and Egypt for Switzerland.

It was not her plan to stay; after her studies and professional training, she wanted to go back to Egypt. From the beginning, she experienced people in Switzerland as cold and distant, and the strict separation between work and private life felt strange and artificial to her. All she wanted - and wants - is "normal" contact with other people, which she finds herself unable to forge: "Ich gehe einfach [...] unterrichten [an der Universität] und [dann] jede geht seinen Weg und [macht] sein Ding und nachher es gibt kein Kontakt mit Menschen" - "I just go teach [at the university] and [then] everyone goes his way and does his thing and after that there is no contact with people," is how she describes her everyday life in Switzerland. At the same time, when she returned to Egypt to visit her family during this first year, she realized that a gap had already opened between herself and her erstwhile home: 
Ich fühlte mich nicht mehr zuhause. Sie haben mich behandelt wie ein Gast und [...] etwas hat angefangen nicht zu stimmen dann. Ich war irgendwie in die Mitte, ich bin nicht dort zuhause und ich bin auch nicht hier zuhause, und ich habe hier [in der Schweiz] mich gewöhnt an alleine zu leben und meine Sachen selber bestimmen, was ich kochen will was ich machen will [...].

I didn't feel at home anymore. They treated me like a guest and [...] something started to not feel right then. I was in the middle somehow, I'm not at home there and I'm not at home here either, and here [in Switzerland] I have gotten used to living alone and deciding on my own, what I want to cook, what I want to do [...].

-Efra Mahmoud

When in Switzerland, Efra Mahmoud misses her vibrant home city, and how people connect to each other there with easy jokes in everyday life. In an attempt to regain this sense of community, she has tried to connect to her compatriots in Switzerland, but it is a small community, and the only friend she made returned to Egypt. She has also sought to establish contact with people in Switzerland over the internet, via a not specifically lesbian chat site. While no friendships have come of this, it is where she eventually met her Swiss partner. She emphasizes that she was not looking for a partner, and she would never have imagined that she was eventually going to engage in a relationship with a Swiss woman who was moreover still married at the time: "Ich wollte nur normal Leute kennen lernen" - "I just wanted to get to know people normally."

Before migrating, Efra Mahmoud had fallen in love with women in Egypt - never with men - but it had never occurred to her to act on her desires or to engage in a relationship with a woman: "Es war für mich einfach nur Gefühle" - "It was just feelings for me." At first, she states that she had not felt as though she was in need of something, that being in love without acting on it felt "okay" and "normal," and that she had not thought much about the implications of her inclinations since she entertained a multiplicity of fulfilling social contacts. However, later in the interview she remarks:

Ich habe nie gedacht dass ich werde etwas eine Beziehung oder etwas machen aberja. [...] Es war mir genug einfach nur gut Kontakt zu haben oder etwas zusammen machen, einfach normal, oder einfach Ceschenke machen, also eher solche Sachen, einfach Liebe zeigen so aber nicht mit mehr. Es hat mir nicht soo gefehlt [...]. Es gab schon Frauen die haben mit mir etwas versucht oder so ausnahmeweise, aber ich weiss nicht warum-das ist nicht normal. Bei uns.

I never thought I will start a relationship or something but yes. [...] It was enough for me just to have good contact or to do something together, just normally, or just give presents, rather things like that, just show love but not more. I didn't miss it sooo much [...]. Sometimes there were indeed women who tried to do something with me or so, but I don't know why-it's not normal. With us [ zback home].

-Efra Mahmoud

Retrospectively Efra Mahmoud asserts that she did indeed miss intimacy (if not "sooo much") when living in Egypt. When still living there, she had also been confronted with the option of acting on these desires but was too afraid of venturing outside of what she 
considered "normal" and into the realm of that which she perceived to be stigmatized as abnormal.

It was only in Switzerland, where Efra Mahmoud fell in love with a professor at university, that she considered acting on her feelings for the first time. She emphasizes that without feelings she could never engage with another woman, but when mutual feelings do arise, this can cause a "problem," as the desire to act can become too strong. Shortly afterward Efra Mahmoud engaged in a relationship with a woman she met online. "Dann ist es schnell gegangen" - "Then it went fast," she says, grinning. At the time of the interview the couple had been together for a couple of years, and had just moved to their own little house in a small town.

Whenever Efra Mahmoud's account touches on issues of same-sex intimacy and sexual identity or relationships, it is marked by hesitation, interruptions, distress, and refusal. At one point she suddenly stops speaking about a love story in Egypt, throwing a meaningful look at the thin wooden panel that separates her own garden (where we are sitting) from her neighbors', who can be heard speaking on the other side of the panel. When asked whether her neighbors know about the nature of the relationship between Efra Mahmoud and her partner, she says that she believes they know but that she has never discussed it with them. In another instance, she explains that in Arabic the word for homosexual and "abnormal" are the same, but refuses to utter or write down the word:

TB: Und wie heisst das Wort auf arabisch, dieses 'abnormal'?

EM: (Fällt resolut ins Wort) Ich sage nicht diese Wort (lacht nervös, hört aufzu reden). [...] Ich $\underline{\text { kann }}$ das nicht weil es ist nur- ich kann das nicht diese Wörter sagen oder schreiben [...] Ich kanns nicht ich kanns nicht einfach, ich kann das nicht, ist nur-ist nicht das ich [nicht] will, ich kann das nicht ich-(hört aufzu reden).

TB: And what's the word in Arabic, this 'abnormal'?

EM: (Interrupts TB resolutely) I don't say this word (laughs nervously, pauses). [...] I can't do this because it's just- I can't say or write these words [...] I can't , I just can't, I can't, it's just- it's not that I don't want to, I can't do it, I- (stops speaking).

-Efra Mahmoud

When asked whether she identifies as a lesbian, Efra Mahmoud replies: "Ich weiss nicht was kann ich mich bezeichnen eigentlich" - "I actually don't know how I can describe myself," and continues:

Das Problem ist dann die meisten denken die lesbische Frauen sie sind-ich interessiere mich nicht an andere Frauen, ich liebe schon jemand und dann das ist fertig, [...] ich habe nicht Interesse an Frauen so wie man das denken wenn man das Wort hört [...], das ist auch ein Grund dass ich will nicht immer dass die Leute denken das ist-ich bin nicht so.

The problem is that most people think that lesbian women they are- I'm not interested in other women, I already love someone and that's it, [...] I'm not interested in women the way you may think when you hear the word [...], that is also a reason that I don't 
want people to think all the time that's-I am not this way.

-Efra Mahmoud

Later in the interview Efra Mahmoud further clarifies what she means by "not being the way" lesbians are perceived to be in Switzerland:

Aber ich kann das [=die sexuelle Orientierung] nicht sagen, ich muss immer aufpassen, und ich habe schon gemerkt zum Beispiel, dass manchmal die Frauen sie sind komisch [wenn] sie wissen dass gibt eine Frau so, [...] auch bei uns am Institut und so, wenn zum Beispiel eine hat Ceburtstag und [eine] umarmt sie oder so, [dann] sagen [sie] 'Ja was will sie von ihr,' solche Sachen, ich will nicht dass die Leute immer denken es gibt etwas, [...] es ist wie ob jemand hat ein Stempel oderso.

But I can't tell people that [=the sexual orientation], I always have to take care, and I have already noticed that sometimes women are strange [when] they know that there is a woman like that, [...] also at our institute, when for instance it's a woman's birthday and a woman embraces her or so, [then they] say 'What does she want from her,' things like that, I don't want people always to think that there is something, [...] it's like someone has a stamp on their forehead or something like that.

-Efra Mahmoud

Efra Mahmoud dissociates herself from stereotypes of lesbians as promiscuous and preying to establish an understanding of herself as monogamous, faithful, and settled, and as someone who only engages with women physically if she also has feelings for this person. The fear of being 'misjudged' as a lesbian critically determines the way Efra Mahmoud manages her sexual orientation in her everyday life. She avoids other lesbians, instead seeking "just normal" contacts, especially with Egyptian compatriots. She does not communicate about her relationship at work or in any other everyday context, especially for fear that an Egyptian might learn about her dissident sexuality, and that this news may spread among the close-knit Egyptian diaspora and eventually back to Egypt to her family. Efra Mahmoud's account attributes to Arab people an exceptional perception of homosexuals: When asked whether she would be interested in participating in a focus group discussion with other queer migrant women, she accepted under the condition that no other Arab participants be present: "Vielleicht wenn sie [die Mitglieder der Fokusgruppe] nicht Arab- [...] weil das Problem ist dass bei uns- wenn jemand von die arabische Länder [...] das Bild für uns ist irgendwie anders, das ist das Problem" - "Maybe if they [the members of the focus group] aren't Arab- [...] because the problem is that back home- if someone from Arab countries [...] the image for us is somehow different, that's the problem." To Efra Mahmoud, the thought of being identified as woman-loving by another (even if also same-sex loving) Arab is unbearable for her.

Efra Mahmoud substantiates her anxiety about gossip by reference to her discovery that she and her doctor have a mutual acquaintance in the Egyptian community. "Das wäre schon problematisch dann" - "this would then be problematic," she says, if this acquaintance were to learn about her sexual orientation. When asked about what she imagines the consequences to be, she answers: 
Das erste Ding dass er wird nie mit mir Kontakt haben für irgendwie ein etwas dann- es ist schlimm obwohl er ist nicht-er ist Christ und alles aber es ist trotzdem... es hat nichts zu tun mit Religion oder so, aber das Bild es für die ganze Ägypter - hat nichts zu tun mit Religion - das ist eigentlich etwas es ist nicht normal. Und ich bin nicht ganz dagegen dass es nicht normal ist, aber ich kann nichts dafür. Es ist- [ich] sage nicht ja zum Beispiel es ist normal und das alles. Okay, das ist schon nicht normal [...].

The first thing is he [the mutual acquaintance] will never have contact with me for something then- it's bad although he's not- he's Christian and everything but in spite of that... it doesn't have anything to do with religion or anything but the image, for all Egyptians - doesn't have anything to do with religion-it's something that is not normal. And I'm not totally against the view that it's not normal, but it's not my fault. It's- for instance I don't say it's normal and everything. Okay, it's really not normal [...].

-Efra Mahmoud

The statement constructs being a "normal" Arab and acting on same-sex desires as irreconcilable concepts. (However, it remains unclear whether Efra Mahmoud refers to same-sex love here, or to acting on same-sex desire, or to forging an identity based on same-sex desire; given her description of her past in Egypt where she felt but did not act on her same-sex desires, it transpires that it is mainly the sexual acts and the act of identification that she considers "not normal.") This situates the speaker in a dilemma: As she identifies as a "normal" Arab, she is required to frame her same-sex desires in terms of abnormality, which pushes her into a defensive position: "It's not normal, but it's not my fault."

At the same time Efra Mahmoud's statement secularizes homophobia in Egypt, stressing that anti-gay attitudes are not connected to religion but are a matter of Egyptian 'culture' at large, which she substantiates by reference to the fact that the Egyptian expat from whom she anticipates a homophobic reaction is Christian and not Muslim. When asked what religion means to her, Efra Mahmoud expresses an intellectual interest in comparative religious studies. To her, religion mainly provides guidelines about right or wrong actions, and she is interested in how religions differ or converge regarding those questions. When asked whether she practices a religion, she reluctantly conveys that she is a practicing Muslim. "Ist eigentlich nicht viel" - "It's actually not much" that you have to observe as a practicing Muslim:

Beten oder kein Schweinfleisch, kein Wein, ja einfach dass man immerschaut dass-zum Beispiel ich kann nicht etwas stehlen [...] oder ich sollte nicht lügen, aber manchmal man muss, aber ich versuche immer das zu vermeiden, solche Sachen einfach [...]. Also (undeutlich) ich sollte nicht mit einer Frau zusammen sein (lacht etwas) also aber-(hört aufzu reden).

Praying or no pork, no wine, yes just that you always see to it that-for instance I can't steal something [...] or I shouldn't lie, but sometimes you have to, but I always try to avoid that, just things like that [...]. Well (mumbling) I should not be with a woman (gives a little laugh), well but- (stops speaking).

-Efra Mahmoud 
At the end of the interview, when asked what she would wish for if she had three wishes, her answer is:

Das ist immer der Hauptwunsch eigentlich, dass wenn ich sterbe ich gehe in das Paradies dann und einfach nicht in die Hölle, dass [...] Gott mir vergibt. Und die zweite Wunsch dass ich bleibe mit meiner Freundin zusammen einfach immer in eine harmonische Beziehung. Und die dritte Wunsch, das ist kompliziert die dritte Wunsch. Ich hätte irgendwie ein Land wo es gibt die Vorteile von hier und von Ägypten in eine gleiche [...] Land beide zusammen. ]a.

This is always the main wish really that when I die I go to paradise and not to hell, that [...] Cod forgives me. And the second wish is that I stay together with my partner always in a harmonious relationship. And the third wish, this is complicated the third wish. I would somehow like to have a country where there are the advantages of here and of Egypt in the same [...] country both together. Yes.

-Efra Mahmoud

Here Efra Mahmoud's ideal of a monogamous and long-term relationship reemerges but, as the first wish indicates, needs to be reread from her perspective as a practicing Muslim who feels she is doing wrong. While she has accepted that she loves women and has decided to live out her homosexuality in spite of her own religious beliefs, she attempts to salvage 'normality' by conforming to normative values in relationships.

In Efra Mahmoud's account, sexuality emerges as an intimate practice restricted to the space of the bedroom rather than an identity. To have her sexual orientation pushed to the forefront of a conversation, as is the case in our interview, assigns sexual preferences a relevance she rejects, repeating that she just wants to live a "decent" (anständig) and "normal" life (implying "...just like heterosexuals") - except for this one admittedly "abnormal" but deeply private thing that happens in the space of the bedroom.

Yet Efra Mahmoud's attempts to confine her queerness to the bedroom failed in the face of Swiss immigration procedure. The fact that at the time of the interview the samesex Partnership Act was not in effect just yet complicated Efra Mahmoud's legal situation. Looking for legal strategies to enable her to stay in Switzerland, Efra Mahmoud and her partner fell victim to an impostor claiming to be able to support Efra Mahmoud in legal proceedings to attain a residence permit. Distressed when rising costs failed to materialize in palpable results, Efra Mahmoud eventually managed to obtain support from the Swiss LGBT community by contacting one of the 'homo-friendly' lawyers listed on the website of the Schweizer Lesbenorganisation LOS, who solved the matter swiftly, competently, and economically.

In other words, Efra Mahmoud's rejection of the lesbian identity is not absolute as she uses it strategically to access resources provided by activist organizations in Switzerland. Still, these necessary moments of identification are marked by reluctance and remain restricted to formal legal issues. Her collaboration with her lawyer has not, for instance, led to an extension of her social relations into the Swiss lesbian community. Instead, Efra Mahmoud has continued to focus her social energy on "normal" Swiss people and expat compatriots, albeit with very limited success.

Efra Mahmoud's narrative about how she and her partner have navigated complex situations such as Efra Mahmoud's immigration process, her partner's divorce, or buy- 
ing and renovating a house confirm her resourcefulness, agency, and resistance in the face of perceived injustice. When things go wrong, it is she - with her limited German - rather than her Swiss partner who picks up the phone and makes the necessary calls to complain, demand, or defend. And yet Efra Mahmoud's palpable discomfort when talking about her sexual orientation made me question why she answered a call to participate in research that explicitly centered on sexuality and migration. ${ }^{11}$ Efra Mahmoud's narrative provides two explanations: first, that she identified with me as a fellow social scientist, expressing empathy for the difficulty of finding research participants. Second, that she applied because my call was mailed to her by the Swiss lawyer who had helped her and to whom she felt obliged. In other words: Efra Mahmoud is not only a woman-loving woman, an Arab, and a practicing Muslim, but also a social scientist, a thankful client of a supportive lawyer, and someone who seeks connection to others.

Returning to Efra Mahmoud's third and final wish, to live in a country that merges the advantages of Egypt and Switzerland, finally directs the focus to her emotional oscillation between the two countries. At one point, when short on work and money, Efra Mahmoud and her partner had planned to move to Egypt:

Ich habe Zeit lang einfach keine Arbeit gehabt und kein Celd einfach [...] und ich wollte schon nach Hause zurück und alles [...], wir [haben] schon mal gedacht [...] ich würde keine Bewilligung bekommen mehr. [...] Sie [Efra Mahmouds Partnerin] war schon bereit mit mir nach Ägypten zurück zu kommen. Aber wir sollten dann bei meinen Eltern wohnen, und sie einfach meine Kollegin oder einfach Freundin oder so. [...] Ich habe einfach gesagt sie hat keine Lust immer kalt und so, und sie wollte scheiden und so, und sie will einfach etwas anderes in ein warmes Land leben [...].

For a while I was unemployed and just didn't have any money [...] and I was ready to go back home and everything [...], we already thought that [...] I wouldn't get a residence permit anymore. [...] She [Efra Mahmoud's partner] was ready to come back with me. But we were supposed to live with my parents, with her just my colleague or just friend or so. [...] I just said she doesn't fancy the cold and all that, and that she wanted to get divorced and all that, and that she simply wants something else, live in a warm country [...].

-Efra Mahmoud

Efra Mahmoud envisions the couples' life in the family house without revealing the nature of their partnership to her family, a strategy which is enabled by the profound silence around female same-sex desire in her family and Egyptian society more broadly. In contrast to the accounts of Augusta Wakari and others, this invisibility and silence around female same-sex desire is positively connoted here: For Efra Mahmoud, Egypt

11 At the time that Efra Mahmoud applied, the call for participants was still explicitly addressed to "lesbians." Hence, her application for this research was another instance in which Efra Mahmoud identified as a lesbian. The wording was changed to "women-loving women" after the first interview. 
holds the promise of a life void of the pressure to 'come out' and assume a (stigmatized) sexual identity. However, the couple abandoned the idea when they realized that it would be much more problematic for Efra Mahmoud's partner to obtain a residence permit in Egypt than vice versa, and not much later Efra Mahmoud found a job in Switzerland, which ended the discussion for the time being.

In sum: Efra Mahmoud is torn between her religious and cultural identities on the one hand and her sexual orientation on the other. Her account grounds her configuration of her sexuality as "abnormal" in her interpretation of the commandments of her religion, which in her eyes leaves no space for doubt that her desire for other women is not normal and that to act on it is wrong. Efra Mahmoud generally refuses to frame her sexual preference and practices in terms of identity, and vehemently rejects the label 'lesbian,' which she perceives as being tied to stereotypical ideas about lesbians such as promiscuity and lechery. Instead, she frames her sexuality as a practice taking place in the private space of the bedroom, which in her eyes should not determine who one is, or keep a person from leading a "normal" life. Efra Mahmoud strives to salvage as much of the normalcy to which she aspires as possible by establishing a homonormative relationship and by connecting to "normal" - non-lesbian - people. However, these efforts are dwarfed by the constant pressure she feels to 'come out' and identify as a lesbian. Sometimes this pressure is explicit: Swiss immigration procedure, for instance, forces her to strategically assume the lesbian identity. At other times, the pressure is subtle and impalpable, little instances in everyday life.

A most crucial lens through which Efra Mahmoud's account and our interaction specifically should be read is further that of homonationalism. Although Efra Mahmoud herself is highly critical of what she describes as an exceptional - that is, excessively negative - attitude many people and public discourses in Arab countries hold against people desiring the same sex, her defense of the Muslim religion and her emphasis on the positive aspects of the culture of silence around same-sex sexuality in Arab cultures are key to her account. As Dervla Sarah Shannahan points out with respect to religion and queerness:

Traditional cultures and perspectives, however they may be envisioned, are posited as necessarily incompatible with queer identity. [...] This modality often takes the atheism of the queer ideal(ized) subject as a foundational premise in such an off-hand manner that it often overlooks faith positions as possible lines of identity or difference. (Shannahan 2010:674)

Efra Mahmoud's often defensive stance and reluctance with respect to topics related to sexuality, culture, and religion suggests that she connected my position as a white Swiss lesbian researcher to a critical, or even negative, attitude towards religion in general and towards Muslim people's treatment of non-normative sexualities in particular. As a white Swiss citizen, I embodied Swiss mainstream culture, where an anti-Muslim racism that configures Muslim people as sexist and homophobic was on the rise in the early 2000 s already (see Chapter 3.4). Efra Mahmoud's narrative is clearly structured by her attempt to work against these prejudices. Her struggle to justify her position and her frequent lack of words thereby testify to the difficulty of reconciling seemingly 
irreconcilable aspects of her Self, such as one's cultural or religious identity with one's sexuality, without being catapulted out of the realm of 'queer' and becoming labelled, once more, as a 'backward' sexual Other having failed to modernize (i.e. to 'come out' and become a 'good lesbian'). At the same time, Efra Mahmoud's narrative works against the implicit foundational atheism Shannahan detects in the certain theorizations of 'queer,' as she indeed simultaneously embodies being a (practicing) Muslim and engaging in same-sex intimacies and relationships. As such, her narrative provides leverage to criticize constricted definitions of sexualities in the realm of 'queer,' and more generally concepts of 'queer' that frame sexuality solely as sexual identities rather than sexual practices or erotic feelings as well (see also Dankwa 2014 and 2021).

\subsubsection{What about non-Migrant Swiss Lesbians?}

Non-migrant queer women's processes of identification subvert a dichotomous understanding of migrant versus non-migrant positionalities with regard to identifying as a lesbian as well. As existing research about lesbians in Switzerland shows, the identification as 'lesbian' by queer Swiss women is not in any way natural or unproblematic (Caprez and Nay 2008, Moser 2001, Rufli 2015, Stefan 1975). Christina Caprez and Eveline Nay argue that many same-sex loving women in Switzerland are reluctant to identify as lesbians, especially those who have never been active in the women's or lesbian movement. Many perceive the term as "hard," as a "swear word," or as having "a negative touch." These connotations are tied to stereotypes that imagine lesbians as women who look and act in a masculine way, something many queer women dissociate themselves from. Lesbians, they feel, are generally perceived as women who are "in men's clothes," "machos," or "women who do not look after themselves, are overweight, do not cultivate themselves, and have a rough way" (Caprez and Nay 2008, my translation). Moreover, many queer women are critical of the sexual focus inherent in the term. As Ulrike Hänsch writes in her account of lesbian biographies in Germany:

Long before the individual woman possibly deals with the question of how to name her feelings or actions, the names for what she does - and therefore is - have long been defined. [...] In order to interpret the stigmatizing sign in a positive way, it first has to be accepted as belonging to oneself. This is why processes of identification are usually fraught with reluctance and contradictions, and these negotiations do not remain limited to the short phase commonly described as coming out. As long as lesbian identity is culturally marked as a corrupt identity, individual identification with it will be rife with contradictions. (Hänsch 2003:242, quoted in Caprez and Nay 2008:304, my translation)

Despite these inherent ambivalences, all of Caprez and Nay's interviewees eventually end up (also) using the term 'lesbian' to refer to themselves, if only for lack of a better alternative. However, many women resort to evasive formulations whenever possible, such as "Ich lebe mit einer Frau zusammen" - "I live with a woman" or "Ich habe eine 
Freundin/Partnerin" - "I have a girlfriend/partner"12 (Caprez and Nay 2008:276). Some of the queer migrant women interviewed here (such as Teresa Ruiz) indeed seem to speak about themselves as Lesben with more ease than Caprez and Nay's interviewees. But language is likely pivotal here: Even in the early 2000 s most women growing up in Switzerland learnt to viscerally shrink away from the phoneme Lesbe/lesbisch or the French lesbienne respectively, while in the home countries of many migrant women who took part in this study this word and concept either did not circulate at all or was only phrased in a foreign language like the English lesbian or the French lesbienne.

In sum, while queer migrant women are positioned in different ways than non-migrant women with respect to the lesbian identity, these differing positionalities should not be interpreted as presenting a dichotomy between migrants and non-migrants in which we assume an unproblematic identification with the lesbian signifier on the part of non-migrants. Images of the 'bad' lesbian emerge from the narratives of both migrant and non-migrant lesbians. As has been shown, this 'bad lesbian' can be a racialized lesbian Other, but it can also be the stereotypical white lesbian inhabiting Swiss lesbian spaces, who is often imagined as promiscuous, masculine, and unable to engage in long-term relationships. This latter image is sometimes also reproduced by women (both migrant and non-migrant) who are no strangers to the lesbian community themselves. Beatriz Krais states that she would only visit the lesbian "ghettos" (=lesbian clubs, events) if she were left with no other choice, such as for instance if she were single; Nermina Petar, Laura Georg, Julia Morricone, and Natascha Schild, all more or less frequenters of lesbian events, frame the lesbian community as a Kuchen (literally 'cake') in which 'everyone has been with everyone,' and in which (according to their observations) relationships never last long. It is against this backdrop that the 'good lesbian' emerges, who commits to long-term monogamous relationships and strives for a normal, depoliticized life.

\subsubsection{Religion and Sexuality}

Efra Mahmoud's account highlights the role of religiousness in the negotiation of samesex desire. Her narrative chiefly grounds her struggle with her sexual orientation in her religious belief system. In her interpretation, this renders her sexuality 'wrong,' and she understands herself as dependent on her god's grace for forgiveness for her behavior and choices. However, Efra Mahmoud's positionality in terms of religion is unique among the narratives that this study examines. In fact, religion is not generally a dominant theme in these accounts of everyday spaces and practices in Switzerland. This may come as a surprise to some, given the tendency in popular discourse in Switzerland to connect non-Western cultures to homophobic orthodox religiosity, especially in the context of Muslim cultures (Puar 2007). It also contrasts with other research on migration conducted in Switzerland, such as Silvia Büchi and Martina Koch's study on migration and health, which found that "almost all persons - no matter their religion - practice their belief, be it at home or through regular attendance at a house of prayer, a church,

12 'Freundin' has a somewhat more serious connotation than the English translation 'girlfriend.' Further, the grammatical gender of 'Partnerin' is feminine - in other words: Where the English term 'partner' covers/invisibilizes homosexuality, the German term exposes it. 
or a mosque, [and] some are also actively engaged in their religious community" (Büchi and Koch 2014:119; my translation). By contrast, few interviewees in this study practice a religion and even fewer do so in an institutional context.

However, this does not imply that the interviewed women did not express any religious or spiritual beliefs, or that for them religion and sexuality co-exist unproblematically. For some of those who grew up in communist societies or were raised in atheist or only moderately religious families, religion was indeed not a predominant issue. However, in other cases the relative absence of religion as an explicit topic in the interviews requires a different reading. These latter life stories suggest that in many instances the silence on the subject of religion is a result of personal development in which interviewees have distanced themselves from and/or transformed their religious belief systems. These developments and transformations are the focus of this sub-chapter. Also, in many biographical accounts religion implicitly emerges as a prominent theme in its role as an intrinsic part of the 'culture' perpetuated by parents, siblings, friends, teachers, the media, and so on. Interviewees' negotiation of these 'cultures' will, however, be discussed in later chapters, especially in Chapters 6 and 7. Lastly, Efra Mahmoud's account further raises the question of who is absent from this study. Against the backdrop of her narrative and the findings of other studies examining the relationship between religiosity and anti-homosexual stances, it stands to reason that orthodox women desiring the same sex often struggle to acknowledge their dissident sexuality and are unlikely to participate in a study such as this. ${ }^{13}$

The religious diversity and complexity within this sample was considerable. A synopsis of parents' denominations and the religious context that interviewees grew up in yields the following structuration: Nine interviewees had Catholic parents, two of whom grew up in a predominantly Muslim context; two had a Serbian/Greek Orthodox background; two grew up in a Christian Free Church context; five had Muslim parents, one (participant) of whom grew up in a communist context; five had parents of different faiths and denominations, including Catholic-Protestant (one of these families was embedded in a predominantly Muslim context), Catholic-Muslim, and atheist-Muslim. One interviewee grew up in a Catholic household but later converted to Mormonism (and also acted as a Mormon missionary in the U.S. for several years); and three had atheist or non-religious parents and grew up in a Muslim, Buddhist/Shinto and communist context respectively. The religious affiliation of participants' parents varied widely, from "Muslim on paper" to "orthodox practicing Catholic."

It is beyond the scope of this research to engage with the many ways in which religion and sexuality constitute each other in these contexts, an enterprise that would be complicated by questions of how religion and 'culture' interrelate, how these interrelations are negotiated in different diasporic contexts, and how these discourses

13 The correlation between religiosity and anti-homosexual stances has been confirmed in international comparative quantitative studies, see e.g. http://www.pewglobal.org/2013/06/04/the-global -divide-on-homosexuality/, downloaded July 15, 2014. As detailed in Chapters 3.4 and 7, such findings always need to be read against the backdrop of global circuits of power. 
are tied into larger geometries of power in a postcolonial world (see Chapter 3.4). Instead, the following sub-chapter attempts to turn one of the major challenges of this research - the diversity of its sample - into a strength, tracing the different ways in which interviewees position themselves vis-à-vis religion, how they perceive this positionality to have shifted through migration and/or their emerging queer desires, and how they draw on religion and spirituality in their everyday lives. As mentioned above, I will focus on accounts concerning personal developments with regard to religion and spirituality. These findings are then considered in light of some insights from the recent flurry of research on religion, migration, and (queer) sexuality.

Frequently, religion was only elaborated on upon request. Interviewees would typically state that they believe in a god or another greater being, often framing their beliefs in terms of spirituality rather than religion. At the same time, these same interviewees would often assert that they do not consider themselves to be particularly religious, that they do not practice their religion - at least not on a regular basis - and/or that they do not practice their beliefs in an institutional context. Besides those for whom religion had never been a prominent issue, there were those whose religious beliefs and value systems had undergone significant shifts. Having grown up in moderately to very religious households, these interviewees later discarded or revised their religious beliefs and practices in the context of their travels and migration, as well as in the course of negotiating their emerging same-sex desires and identities. Vehement selfdoubt, shame, isolation, and a sense of 'wrongness' often marked the starting point of such theological transformations. Although these crises should be understood as a result of homophobias as cultural phenomena rather than specifically religious ethics alone, interviewees frequently connected the adversities they had experienced as sexual dissidents to the religious beliefs of people in their home countries, especially their parents.

The periods of self-doubt were often followed by at least a partial rejection of religion. In many cases religious practices such as going to church or daily prayer were laid to rest. At the same time, core values were retained, although often framed in terms of spirituality rather than religion. Charlotta Sembiring, who grew up in a strictly Catholic household in Indonesia and was very actively engaged in her religious community as a young adult explains her belief as follows: "I certainly believe in something bigger, a bigger scheme or a bigger- something that sort of connects everything, people, the earth, the universe. So I believe in a connection- but I have a hard time with God." This statement exemplifies the religious and spiritual attitudes expressed in many other accounts.

The emancipation from homophobic interpretations of religion, typically embodied by orthodox parents, happened either through an incorporation of other religions or spiritual worlds into one's belief system, or through a rereading of a specific religion from a queer perspective. As Jimena Reyes, who grew up in a Catholic household in Peru, recounts the evolution of her religious beliefs: 
douisme, j'ai trouvéça tellement sage, tellement, philosophique, d'une ouverture et d'une pureté exemplaire, et du Bouddhisme encore plus, tu vois. Et moi, je prends tout. Tout ce qui est possible, mais je ne suis pas une ligne. Donc je veux être libre avec ma religion.

I'm an ecumenist. Me, I take the best of everything. From Islam, from Catholicism since this was my primary education, then when I arrived in India and discovered Hinduism, I found this so wise, so, philosophical, of an exemplary openness and pureness, and Buddhism even more, you see. And me, I take everything. Everything that is possible, but I'm not one line. So I want to be free with my religion.

一]imena Reyes

Jimena Reyes' deliberations about religion constitute an intrinsic part of her reflections about how her relationship to the gay and lesbian community in Switzerland has changed. Before going to India, she had spent quite some time in gay and lesbian spaces, but after engaging with Hinduism and Buddhism she has increasingly come to perceive these spaces as confining "ghettos":

C'est le voyage en Inde c'est cette philosophie différente, cette ouverture magnifique de l'Hindouisme et du Bouddhisme qui m'a permis à m'ouvrir plus quoi, ne pas rester sur des réseaux ou des ghettos ou des choses comme ça, moi j'aime tout le monde, les Noirs les Chinoises, les hétérosexuels les transsexuels enfin j'aime tout le monde, et j'ai pas du tout envie de me sentir uniquement dans un certain lieu.

It's the trip to India, this different philosophy, this magnificent opening of Hinduism and Buddhism that has allowed me to open myself up more, not to stay within certain networks or ghettos or things like that, me I love everybody, the Blacks the Chinese the heterosexuals the transsexuals, I love everybody, and I don't feel like feeling at home in one specific place only.

一 Jimena Reyes

Religion has remained an important part of Jimena Reyes' everyday life. Her values and beliefs directly manifest themselves in her social practices as well as in the way she positions herself within the lesbian community. In her everyday life she surrounds herself with religious objects and images: Among her pictures taken for this research is one featuring a poster of the Hindu god Ganesha, a figure that reappears on a picture of a poster she has put together herself, consisting of a collection with photos of the vast array of people - family and friends - who are important in her life: "J'ai fait des photos aussi de Ganesh, donc le côté spirituel, pour moi est très important, ça fait partie de mon équilibre, [...] ces objets-là [les photos, Ganesha], je suis toujours avec" - "I also took pictures of Ganesh, so the spiritual side, for me it's very important, it's part of my equilibrium, [...] these objects here [the photos, the Ganesha poster], I'm always with them."

Others, like Julia Morricone, literally reread their religion from a queer perspective in an effort to reappropriate their religious 'home' and to reconcile their religious and 
sexual identities. ${ }^{14}$ As a teenager, Julia Morricone met her future partner in their Free Church community, of which both of their parents were members. ${ }^{15}$ After admitting their mutual affection to each other, the women went through a period of 'we would like to but we shouldn't, restricted by a sense of shame rooted in their religious upbringing. This period lasted over a year, but eventually the couple decided to commit to their relationship and leave their religious community. They considered initiating a situation in which they would be forcibly expelled in order to coerce the community members to openly discuss the issue of homosexuality, but eventually refrained from this strategy in order to spare Julia Morricone's mother, who was a leading figure in this community. After this break, Julia Morricone lost interest in religion altogether for several years: "Ich habe wie ein bisschen eine Funkstille gehabt" - "There was like an absence of communication ["radio silence"] for a while." Years later she realized that she was missing something, so she and her partner established a reading group to bring together queer people who shared their desire to engage with the Christian religion and discuss biblical texts from a queer perspective. However, it was in the context of this group that Julia Morricone understood that the religious 'home' she sought to re-establish in the end remains unattainable because it, importantly, had been the banal, daily rituals and routines of her specific Free Church that had provided her with a sense of familiarity and security. "Es ist etwas verloren gegangen" - "Something got lost," she concludes with regret.

Efforts to realign homosexuality with religious beliefs are often marked by a sense of confusion, ambivalence, anger towards god, or even self-hate. If god is good, why should god say "Okay Nora, du bist lesbisch aber ich verbiete dir lesbisch zu sein, jetzt kämpfe du mal und ich hocke auf meinem Sessel und schaue dir zu wie du damit fertig wirst" - "Okay Nora, you are a lesbian, but I forbid you to be a lesbian, now go and fight while I watch from my easy chair how you deal with it" (Nermina Petar)? This question also occupies Maria Borkovic:

I mean if it's like Cod also made gay people you know (laughs), who are we coming from then? Like, we still exist and you know God loves everyone even you know big terrorists and killers, you know Cod forgives everyone. [...] It cannot bad really if it comes from love, I think it's really like how the Bible was read or maybe some sections were taken out, you know these things which are there and I think it's more the church like Catholic Church made these big problems around gay people and around these relationships. -Maria Borkovic

Here the mystery of a god that created not only homosexuals but also homophobia is resolved in an interpretation of homophobia as a technology of power within the Catholic Church. At the same time, the alignment of homosexuality with terrorism and murder

14 I owe the concept of rereading religion to Andrew K.T. Yip's analysis (2005) of how queer Muslims and Christians reread religious texts.

15 As a side note: Julia Morricone's account of how she met her partner also highlights the often very circumstantial nature of religious membership: Many an interviewee joined a church group or activity simply because she had fallen in love with the priest's daughter or another member of her religious community. 
exposes this statement as a manifestation of the homophobia Maria Borkovic continues to direct at herself. As she asks later in the interview with regard to the fact that she cannot conceive a child for medical reasons: "Does that mean I'm really breaking the rules here"? Nermina Petar seems to summarize what many others experience when saying that: "Ich glaube an Gott. Also ich habe immer irgendwie Angst zu sagen irgendwie es gibt kein Gott. Bist damit aufgewachsen und die Religion selber bedeutet dir etwas" - "I believe in God. Well I'm always somehow afraid to say somehow that there is no God. You grew up with it and the religion means something to you." Here religion emerges as a technology to discipline sexuality, drawing its efficacy from its intimacy ("You grew up with it"). It is precisely this familiarity, coupled with fear, which can render complete dissociation impossible.

The biographical narratives discussed here suggest that those who grew up in a religious context that condemned homosexuality have revised their belief systems in order to realign their theological or spiritual framework with their emerging same-sex sexuality. In the course of these developments, the personal significance of religion has often, but not always, decreased. These shifts are marked by an initial sense of shame and self-doubt, followed by a partial rejection of beliefs and practices, and eventually by the creation of a belief system that can accommodate same-sex sexuality in positive terms. At the same time, this process is often partial and selective, which exposes (certain restrictive interpretations of) religions as intimate technologies for disciplining sexuality that do not allow believers to discard homophobic beliefs easily, resulting in persistent internalized homophobia and a struggle to establish a positive view of one's sexuality.

In this context, it is further important to note that homophobia is not contingent on religiosity alone: Many non-religious parents also reacted negatively to interviewees' dissident sexuality. Nor are these instances of homophobia contingent upon 'culture.' As discussed in Chapter 3.4, accounts that ground homophobia in religion and/or culture, ethnicity, or nationality in essentialist ways need to be reread in the context of global geometries of power. Rather than situating homophobia in non-Western (notably Muslim and African) cultures, such a reading reframes modern homophobias as a result of the dichotomy between the Western Self and the colonial Other. Yet, at the same time, it must not be forgotten that queer people's self-doubts, shame, and struggles with parents who try to discipline their queerness remain painful realities.

To conclude, I turn the focus back to queer migrant women's reinventions and reappropriations of religion and spirituality. In line with Shannahan's earlier argument that atheism seems to have become an implicit foundational premise for the queer ideal(ized) subject, Andrew K.T. Yip argues that Western discourses tend to render religion as something backward and sex-negative (and hence something that readily attaches itself to circulating imaginations of the colonial Other):

In the increasingly secularized West at least, religion is generally perceived as sex-constraining (i.e. it hegemonizes heterosexual marital-sexuality and constructs all other forms of expression as an unacceptable 'Other'), if not sex-negative (i.e. it represses and oppresses believers as sexual beings, thus undermining their humanity). From 
this point of view, religious understanding of sexuality is often incompatible with broader social and cultural developments that are moving towards greater liberalism and recognition of sexual diversity and pluralism, as well as individual embodied sexual rights and autonomy. Therefore, religion appears out-of-step with the times [...]. (Yip 2009:1-2)

Queer migrant women's revisions, reinterpretations, and recompositions of their religious and spiritual belief systems upset the logic Yip so aptly describes. Although often accompanied by persistent internalized homophobia, interviewees' reappropriations of religion and spirituality often establish perspectives on religion and spirituality that can accommodate queerness and as such are sex-positive. These recomposed belief systems often represent an intrinsic part of interviewees' everyday lives and provide them with a sense of orientation and belonging.

In this sense, queer migrants' reclamation of religion and spirituality as they emerge from the interstices of upbringing, queerness, and migration are productive of new ways of thinking about religion and sexuality. Yet Yip warns us that queer migrants' revisions of their belief systems should not be framed in terms of queerness and agency alone. He argues that individualizing religion from a queer perspective "generally reflects the contemporary western religious landscape that prioritizes the authority of the Self over that of religious institution" (Yip 2005:47). From this, the creation of an individualized, tolerant, and queer religious belief system emerges as another milestone in the neoliberal project of reinventing the Self in the context of a migration project:

Processes such as de-traditionalization and individualization have significantly undermined the basis of traditional authority, leading to the empowerment of the self. Life, therefore, has become increasingly a strategic trajectory in the construction of social biography [...]. Indeed, in the case of non-heterosexual Christians and Muslims, queering religious texts becomes one of the strategies to construct 'do-it-yourself' social biographies to achieve identity coherence and continuity. (Yip 2005:59, references omitted)

Correspondingly, queer migrant women's revisions of religion also have to be read alongside the process of developing a lesbian identity. While such 'do-it-yourself' belief systems provide a theological or spiritual sense of orientation and emancipation from parents' beliefs, they at the same time reflect a process of disciplining that may also be read as part and parcel of becoming a 'good lesbian.'

In her deliberations about Muslim faith and queerness, Shannahan contends that queer theorists' conceptualization of queer as a decidedly anti-identity stance also encodes ideal queer spaces, cultures, and identities as implicitly secular as the queer ideal of 'freedom of norms' becomes conflated with 'freedom from religion.' This problematizes the membership of faithful queer people in the queer community, in which "visible signs of religious observance are oft read as blotting out the very possibility of lesbian identity" (Shannahan 2010:674). Especially in the context of migration, sexual liberation' and membership in the queer community is often paired with the rejection of a traditional culture that is experienced as oppressive, and of which religion is seen to be an intrinsic part. Taking queer migrants' faith and spiritual positions seriously as 
"possible lines of identity or difference" (ibid:675) by contrast offers the possibility to frame transnational configurations of sexuality and religion as a global circuit instead of a unilateral spreading of Western (secular) queer ideals.

\subsubsection{Conclusion}

Under the title "It's like a stamp" this sub-chapter engaged with the migration biography of Efra Mahmoud, who does not identify as a lesbian and does not generally frame her sexuality in terms of an identity. Her account grounds her reluctance to identify as a lesbian in her religious beliefs and her consequent understanding of her sexuality as "abnormal." Efra Mahmoud's rejection of the lesbian label was then juxtaposed with non-migrant lesbians' positionalities, for whom the lesbian identity is also problematic. From this, it was concluded that although migration necessarily triggers shifts in sexual positionalities, these are not to be understood in terms of a dichotomy between migrants who have a problem with the lesbian identity and non-migrants who do not. A second juxtaposition compared the trajectory of Efra Mahmoud's religious identity with those of other interviewees'. While religion and spirituality often serve as points of reference in interviewees' everyday lives, in the majority of the accounts, religion does not emerge as a dominant theme. Some of those accounts were shared by interviewees who had grown up in secular or only mildly religious contexts, but most had seen a shift in their faith and belief systems through migration and the emergence of their same-sex desires. A critical queer postcolonial perspective frames queer migrant women's rejections, reappropriations, and reinterpretations of their faiths in terms of a secularization of queer migrant subjects in the process of becoming 'good lesbians,' that is, ideal individualized, secular queer subjects. Against such a purely structural view, it was argued that these reappropriations of faith also should be read as contributions to the transnational circuits of religion and desire, and in this sense as new perspectives on religion, spirituality, sexuality, and queerness.

\subsection{Conclusion}

This chapter engaged with the question of how queer migrant women's understanding of their sexual Selves has shifted through the experience of migration. From the discussion of their migration biographies, it was found that these shifts necessarily entail a renegotiation of sexuality in the home country on the one hand and situating oneself vis-à-vis the lesbian identity pervading dominant Swiss discourses on the other. The chapter highlighted three trajectories of shifting sexualities, with one case study serving as the principal example for each: Teresa Ruiz, who had not thought of her sexuality in terms of same-sex desire before she came to Switzerland but has developed a lesbian identity since; Siti Mohd Amin, who had been a member of a sexual minority community in Malaysia before emigrating; and Efra Mahmoud, who did not think of her same-sex desires in terms of an identity before leaving Egypt and continues to resist the lesbian "stamp" in the diaspora. 
No matter whether the lesbian identity is rejected or adopted, these processes of disidentification remain partial, precarious, ambivalent, and contradictory. Rejection of the lesbian label is rendered incomplete as queer migrants are permanently confronted with the lesbian stereotypes pervading everyday and institutional spaces and places. Moreover, sometimes strategic identification can be required to gain access to resources, such as a lawyer specializing in homosexuality and immigration. Identification with the lesbian label equally remains partial through (sub)cultural difference and mechanisms of exclusion in lesbian spaces (including self-exclusion) that reveal that the seemingly neutral lesbian figure is always already Western and white.

Like migration narratives in general, accounts of shifting sexualities are always also stories of personal development. Sexuality emerges as a crucial site for constructing the Self, and as such represents a decisive factor in the success of the migration project as a whole. The analysis subjected this narrative pattern to a double and contradictory reading. First, these reinventions of the sexual Self were framed in terms of agency. Queer migrants make decisions, migrate, offer resistance, tackle negotiations, reject politics, instrumentalize identities, overcome repulsions, navigate new cultural contexts, forge contacts, reshape lives, heed traditions, yield to desires, make sexual choices, maintain transnational ties, manage everyday lives, and reflect sexualities. Their strategies to navigate the paradoxes of their corporeal presence as queer migrant women in an environment in which there are no designated spaces for queer migrant women is shown to be productive of understandings of the lesbian identity - and more generally sexualities - that expose, disturb, and undermine dominant ideas in Swiss discourse about the figure of the lesbian and sexuality.

Second, these sexual/migration biographies were read from a critical postcolonial perspective. As all three cases highlight, adoption or rejection of the lesbian identity is pivotal to social in- or exclusion in Swiss everyday life. While a rejection of the lesbian identity tends to result in social isolation and (sometimes partly self-inflicted) exclusion, identifying as a lesbian is a crucial milestone on the way to successful 'integration' into Swiss society. Such stories of réussite are often about becoming a 'good lesbian,' which entails the adoption of homonormative ideas about sexuality, relationships, and procreation as well as, importantly, the retrospective construction of a lesbian biography and coming-out story.

At the same time, narratives that describe migrations as 'homecomings' to the lesbian identity are paired with stories of social exclusion (deskilling, failure to gain access to the lesbian community, and so on), which unmask Switzerland as a space where migrants - and queer migrants in particular - continue to be discriminated against based on their being perceived as Ausländerinnen. Thus, the adoption of the lesbian identity by queer migrant women also needs to be read as a strategy to escape racial and ethnic markings. This reading resonates with Adi Kuntsman's analysis (2003) of the migration biographies of Russian lesbians in Israel. Kuntsman shows how Russian lesbians in Israel adopt a lesbian identity to escape racial and ethnic Othering, since the subcultural codes of the Israeli lesbian identity - short hair, boyish clothes - allow Russian lesbians to pass as Israeli-born middle class lesbians. As Kuntsman comments on her own experience: "I am again marked as different - this time in terms of sexuality and gender 
rather than race or ethnicity. The former difference is a result of my deliberate choice, and I like to narrate it as liberation of the body and consciousness" (ibid:300).

Although social markers such as skin color, name, or language denied the option of 'passing' like this to some interviewees, the desire to blend in was a recurrent and dominant theme across accounts. While the lesbian identity seems to offer such an opportunity to become a part of something bigger, inserting oneself into Swiss lesbian spaces space comes at a cost and eventually places queer migrants, as 'double impossible subjects,' in a paradoxical position: On the one hand, sexualized and racialized discursive formations render it impossible to be both a citizen of one's home country and a member of one's ethnic, religious, or cultural diasporic community and a (Swiss) lesbian; on the other hand, it is equally impossible to be a lesbian and an immigrant with a different cultural background and a different understanding of sexuality. 